\title{
NF1 regulation of RAS/ERK signaling is required for appropriate granule neuron progenitor expansion and migration in cerebellar development
}

\author{
Efrain Sanchez-Ortiz, ${ }^{1,2}$ Woosung Cho, ${ }^{1,2}$ Inga Nazarenko, ${ }^{1,2}$ Wei Mo, ${ }^{1,2}$ Jian Chen, ${ }^{1,2,3}$ and Luis F. Parada ${ }^{1,2}$ \\ ${ }^{1}$ Department of Developmental Biology, ${ }^{2}$ Kent Waldrep Foundation Center for Research on Nerve Growth and Regeneration, \\ University of Texas Southwestern Medical School, Dallas, Texas 75390, USA
}

\begin{abstract}
Cerebellar development is regulated by a coordinated spatiotemporal interplay between granule neuron progenitors (GNPs), Purkinje neurons, and glia. Abnormal development can trigger motor deficits, and more recent data indicate important roles in aspects of memory, behavior, and autism spectrum disorders (ASDs). Germline mutation in the NF1 tumor suppressor gene underlies Neurofibromatosis type 1, a complex disease that enhances susceptibility to certain cancers and neurological disorders, including intellectual deficits and ASD. The NF1 gene encodes for neurofibromin, a RAS GTPase-activating protein, and thus negatively regulates the RAS signaling pathway. Here, using mouse models to direct conditional NF1 ablation in either embryonic cerebellar progenitors or neonatal GNPs, we show that neurofibromin is required for appropriate development of cerebellar folia layering and structure. Remarkably, neonatal administration of inhibitors of the ERK pathway reversed the morphological defects. Thus, our findings establish a critical cell-autonomous role for the NF1-RAS-ERK pathway in the appropriate regulation of cerebellar development and provide a basis for using neonatal ERK inhibitor-based therapies to treat NF1-induced cerebellar disorders.
\end{abstract}

[Keywords: Neurofibromatosis type 1; cerebellum; granule neuron progenitor; NF1; CNS development; barrel cortex] Supplemental material is available for this article.

Received June 2, 2014; revised version accepted September 22, 2014.

The cerebellum regulates higher cognitive functions in the brain, including balance, motor coordination, speech, memory, and learning (Steinlin 2008; Hatten and Roussel 2011). Cerebellar development in mice initiates during embryogenesis and continues postnatally (Hatten and Heintz 1995). The postnatal phase of cerebellar development encompasses overt morphogenesis brought about by a concerted regulation of proliferation, differentiation, and migration of neural progenitors. It also requires the coordinated interaction between stem/progenitor cells, neurons, and glia to refine the structure of the cerebellar cortex as a three-layered laminar configuration (Roussel and Hatten 2011). The molecular layer (ML) is an outer layer that contains the axons of granule neurons, Purkinje neuron dendrites, Bergmann glia (BG) fibers, and basket and stellate cells. The middle Purkinje cell layer (PL) is composed of the cell bodies of Purkinje neurons and BG. Last, the innermost internal granule cell layer (IGL) contains the most abundant cell type in cerebellum, the granule neurons. Granule neuron progenitors (GNPs) are generated during embryogenesis at the rhombic lip and migrate tangentially across the surface of the cerebellar primordium to form the transient external germinal layer (EGL), the most superficial cerebellar layer (Alder et al. 1996; Wang et al. 2005). At birth, EGL GNPs actively divide and migrate inwardly through BG processes and past Purkinje cells to form the IGL, where they differentiate and mature into glutamatergic neurons (Xu et al. 2013). In mice, GNP migration takes place in postnatal weeks 1 and 2 and is completed by the third postnatal

(C) 2014 Sanchez-Ortiz et al. This article is distributed exclusively by Cold Spring Harbor Laboratory Press for the first six months after the fullissue publication date (see http://genesdev.cshlp.org/site/misc/terms. xhtml). After six months, it is available under a Creative Commons License (Attribution-NonCommercial 4.0 International), as described at http://creativecommons.org/licenses/by-nc/4.0/.
${ }^{3}$ Present address: Institute of Functional Nano and Soft Materials (FUNSOM), Soochow University, Suzhou, Jiangsu 215123, China Corresponding authors: luis.parada@utsouthwestern.edu, chenjian2014@ suda.edu.cn

Article is online at http://www.genesdev.org/cgi/doi/10.1101/gad.246603.114. 
week. By this time, the EGL is no longer present, and the well-defined cerebellar layers have fully formed.

The NF1 tumor suppressor gene encodes for neurofibromin, a RAS GTPase-activating protein (GAP) that promotes the conversion of an active RAS-GTP-bound form to an inactive RAS-GDP form and functions to negatively regulate the activity of RAS effectors, including the RAF-MEK-ERK signaling pathway (Cichowski and Jacks 2001; Zhu et al. 2001). Inactivating germline mutations in NF1 cause Neurofibromatosis type 1 (NF1), an autosomal inherited disorder that affects approximately one in 3000 individuals (Tidyman and Rauen 2009). NF1, along with other related developmental disorders, has been classified as a neuro-cardio-facialcutaneous (NCFC) syndrome or "RASopathy," where germline mutations occur within components of the RAS/ERK signaling pathway (Schubbert et al. 2007; Samuels et al. 2009; Tidyman and Rauen 2009). In the brain, the ERK pathway is involved in critical processes that include development, cell survival, genesis of neural progenitors, learning, and memory (Samuels et al. 2009). More than half of the individuals diagnosed with NF1 display cognitive impairment (Costa and Silva 2003; Samuels et al. 2009). It has been estimated that between $30 \%$ and $70 \%$ of NF1 patients have learning disabilities (Hyman et al. 2005). In addition, $\sim 1 \%$ of children with autism spectrum disorders (ASDs) are eventually diagnosed with NF1 (Marui et al. 2004), and more recent studies indicate a significant incidence of ASDs in NF1 individuals (Garg et al. 2013). Genetically engineered mouse models (GEMMs) with heterozygous or conditional NF1 inactivation have behavioral phenotypes related to learning disabilities (Cui et al. 2008). Despite the clear implications of NF1 in cognition, the developmental basis and associated cellular and molecular mechanisms are not completely elucidated.

Evidence stemming from clinical studies and GEMMs has hinted at important functions for NF1 in various aspects of CNS development. It has been shown that some NF1 patients exhibit brain cortical structure abnormalities (Balestri et al. 2003). Mice with targeted ablation of NF1 in selected brain regions exhibit diverse phenotypic consequences. For example, NF1 mutant cortical radial glia progenitors fail to form cortical barrels in the somatosensory cortex (Lush et al. 2008). NF1 ablation in adult hippocampal neural progenitors exhibits enhanced proliferation and increased generation of new neurons (Li et al. 2012). NF1 inactivation in neonatal neural progenitors of the subventricular zone (SVZ) exhibited increased gliogenesis accompanied by reduced neurogenesis and an enlarged corpus callosum (Wang et al. 2012). Collectively, these lines of evidence provide a clear implication and precedence for NF1 function in CNS development.

In the present study, we examine the role of NF1 in mouse cerebellar development. We show a critical role for NF1 in appropriate GNP proliferation in the EGL and neuronal migration into the IGL. Thus, NF1 loss disrupts normal cerebellar folia development. Our data add the cerebellum as an important CNS target for NF1 loss in neurofibromatosis and provide evidence that specific pathway targeted therapeutic strategies may reverse NF1-related cerebellar defects.

\section{Results \\ Embryonic NF1 deletion in radial glia disrupts cerebellar development}

Previous studies using the well-characterized human GFAP-cre transgenic mouse line (hGFAP-cre) (Luikart et al. 2005; Li et al. 2008) have documented a role for NF1 in the development of several CNS regions, specifically in cortical barrels in the somatosensory cortex (Lush et al. 2008) as well as the olfactory bulb and corpus callosum (Wang et al. 2012). hGFAP-cre expression starts between embryonic day 11.5 (E11.5) and E12.5 and in telencephalon is first detected in radial glia, which give rise to both neuronal and glial cells (Zhu et al. 2001). As such, cre recombinase expression is strong in the forebrain (Lush et al. 2008) and later in the cerebellum, as assessed by LacZ reporter gene expression (Fig. 1A). We turned to the $h G F A P$-cre line to examine NF1 function in cerebellar development. Immunofluorescence studies performed on sections of 1-mo-old hGFAP-cre transgenic mice crossed to Rosa26 reporter mice expressing LacZ or GFP confirmed cre-recombinase activity in granule neurons and glial lineages but not in Purkinje neurons (Fig. 1B). This observation was further confirmed using the Z/EG reporter line (Supplemental Fig. 1A; Novak et al. 2000; Lush et al. 2008), demonstrating that the majority of cells in the cerebellum, excluding Purkinje neurons, had undergone recombination. We then crossed $N F 1^{\text {flox } / \text { flox }}$ mice into the hGFAP-cre background (hereafter referred to as NF1 ${ }^{\text {hGFAP }}$ mice). Western blot analysis of whole cerebellum lysates using anti-NF1 antibody showed $\sim 80 \%$ protein reduction in the NF1 ${ }^{\text {hGFAP }}$ cerebellum (Fig. 1C). The remaining NF1 protein likely resides in Purkinje neurons and local oligodendroglia that do not undergo recombination and residual cre transgene inefficiency (Supplemental Fig. 1A).

NF1 ${ }^{\text {hGFAP }}$ mice displayed enlarged cerebral cortex and reduced olfactory bulb size, consistent with recent reports (Fig. 1D; Wang et al. 2012). Mutant animals showed an increased brain to body weight ratio due to their enlarged cortex, which was apparent by postnatal day 12 (P12) and further evident at P28 (Fig. 1E). The NF1 ${ }^{\text {hGFAP }}$ mice also exhibited a notably smaller cerebellum compared with controls (Fig. 1D). We further examined the basis of diminished cerebellar size by histological analysis. Hematoxylin and eosin (H\&E) staining of cerebellar sections indicated that while at P2 cerebella from control and mutant mice appear indistinguishable, by P12, the mutant cerebella showed morphological disorganization with an ill-defined IGL (indicative of a paucity of granule neurons) (see below) that became magnified over time. Figure $1 \mathrm{~F}$ illustrates the severe misalignment of the cells in the PL and granule cell layer (GCL) at P28. The NF1 ${ }^{\text {hGFAP }}$ cerebella retain abnormal cell clusters at the pial surface, the site 


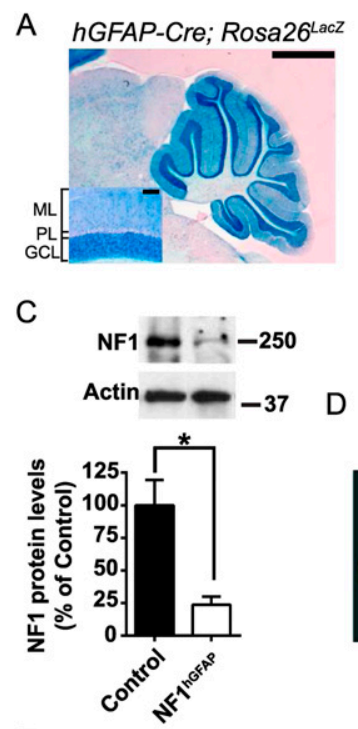

F
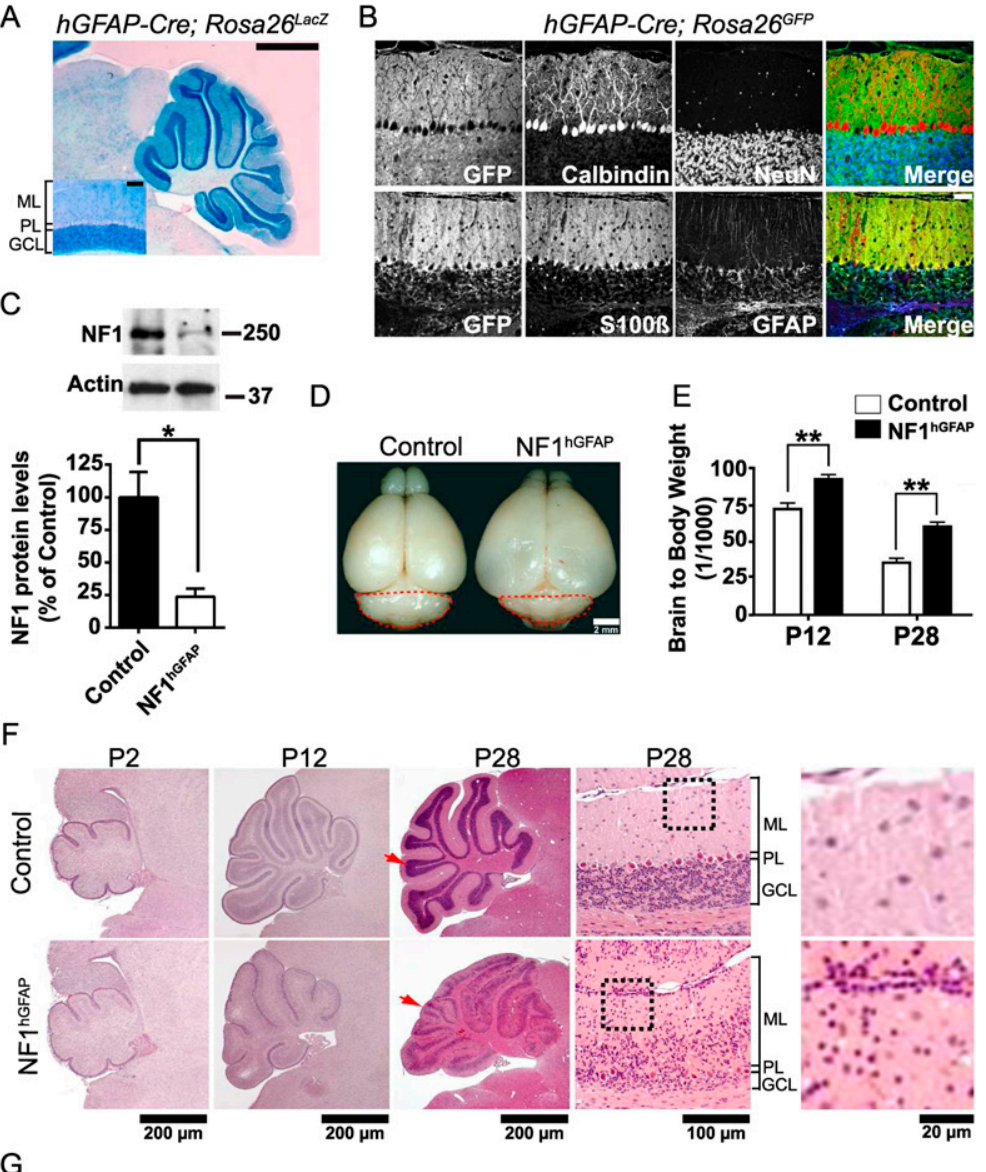

G

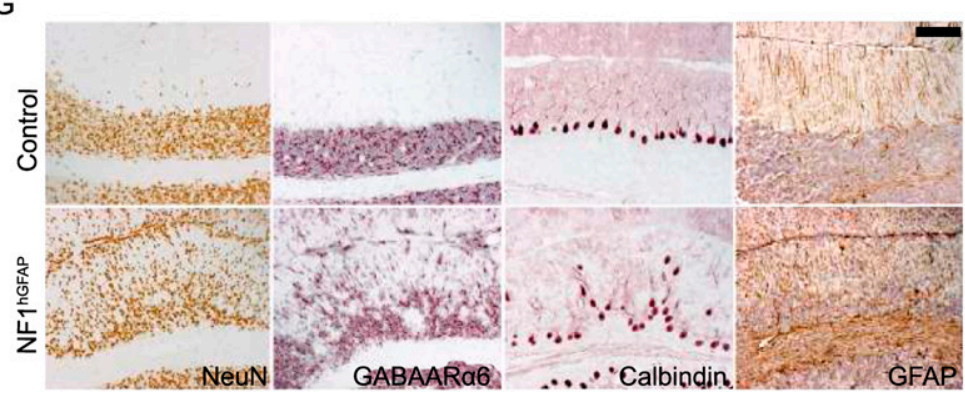

Figure 1. NF1 ${ }^{\text {hGFAP }}$ mice exhibit abnormal cerebellum. (A) X-Gal staining of a 1-mo-old hGFAP-Cre Rosa26 LacZ mouse cerebellum. Inset is a high-magnification view of folium IX. Note that X-Gal staining is present in the GCL but not the PL. Bars: $1 \mathrm{~mm}$; inset, $100 \mu \mathrm{m}$. (B) Immunofluorescence staining for cre-recombinase expression, as indicated by GFP, in the neuronal and glial lineages of a 1-mo-old hGFAP-cre;Rosa26 $6^{G F P}$ reporter mouse cerebellum. Bar, $100 \mu \mathrm{m}$. $(C)$ Western blotting and quantification of NF1 in control and NF1 $1^{\text {hGFAP }}$ whole cerebellar lysates. Molecular weight markers (in kilodaltons) are shown. Mean $\pm \mathrm{SEM} ; n=3 ;\left(^{\star}\right) P<0.05$. $(D)$ Representative whole-mount images of control and NF $1^{\text {hGFAP }}$ brains. The cerebellum has been circled by red dashed lines. $(E)$ Analysis of the brain weight to body weight ratio of control and mutant mice. Mean \pm SEM; $\left.n=5 ;\left.\right|^{\star \star}\right) P<0.01$. (F) H\&E staining of cerebellar sections from control and NF1 $1^{\text {hGFAP }}$ mice shows dysmorphology in mutant mice. Red arrows indicate folium VII at P28. Higher magnification of folium VII is shown in the adjacent right panels. Note the presence of abnormally retained cell clusters at the pial surface (EGL) of the mutant cerebellum (black dotted line boxes are magnified in the panels at the far right). (G) Immunohistochemistry of control and NF1 ${ }^{\text {hGFAP }}$ mouse sections with NeuN (granule neuron), GABAAR $\alpha 6$ (granule neuron), calbindin (Purkinje neuron), and GFAP (BG) antibodies indicates defective folia layering and gliosis. Bar, $100 \mu \mathrm{m}$. of the neonatal transient EGL, at a time when this outer region is no longer present in control mice (Fig. 1F). Immunohistochemical analysis performed in cerebellar sections of 1-mo-old mice with markers for granule neurons (NeuN and GABAAR $\alpha 6$ ) and Purkinje neurons (calbindin) further documented the disorganization of these neuronal cell types and aberrant alignment of the corresponding layers in the mutant cerebellum (Fig. 1G). NF1 ${ }^{\text {hGFAP }}$ cerebella also displayed higher levels of endogenous GFAP immunoreactivity, indicating reactive gliosis accompanying the acute folia structural changes. In addition to misalignment, the Purkinje neurons in 2mo-old mutant mice retained immature morphological characteristics, including decreased dendritic tree width and length, thus indicating their inability to properly mature (Supplemental Fig. 1B). Because hGFAP-cre is not expressed in Purkinje neurons, the observed defect in these cells is likely to be secondary to abnormalities in granule neurons or BG. Taken together, these data indicate that embryonic NF1 ablation in the cerebellum alters its proper development by disrupting foliation, cellular organization, layering, and overall morphology.

\section{NF1 ${ }^{\text {hGFAP }}$ mice exhibit defective GNP migration and proliferation}

Early postnatal cerebellar development involves a massive proliferation of GNPs in the EGL and their inward migration along BG processes, accompanied by differentiation to form the granule neuron IGL (Roussel and Hatten 2011; Buffo and Rossi 2013). To assess the cellular mechanisms responsible for the cerebellar defects observed in NF1 ${ }^{\text {hGFAP }}$ mice, we first sought to assess neuronal migration defects. Control and mutant mice were 
administered bromodeoxyuridine (BrdU) at P7, as GNP proliferation peaks around this age (Roussel and Hatten 2011), and the number of BrdU-incorporating cells in the IGL was examined after a 5-d chase. Immunofluorescence with BrdU antibody revealed a markedly reduced number of BrdU-incorporating cells in the mutant IGL compared with control (Fig. 2A,B). In addition, at P12, an increased number of BrdU-incorporating cells was retained at the mutant EGL (Fig. 2A, arrowheads), indicating impairment of GNP migration in NF1 ${ }^{\text {hGFAP }}$ mice. We next assessed GNP proliferation by administering BrdU at P7 and monitoring rapid incorporation in the EGL after a 2 -h chase. At P7, the NF1 ${ }^{\text {hGFAP }}$ EGL exhibited an approximately twofold decrease in the number of BrdUincorporating cells compared with controls (Fig. 2C,D). NeuN immunostaining and nuclear staining at $\mathrm{P} 7$ also show the severe disorganization of the mutant GCL and the increased number of cells at the ML (Fig. 2A,C). Together, these data indicate that the alteration in the folia layering and structure in NF1 ${ }^{\text {hGFAP }}$ mice occurs as
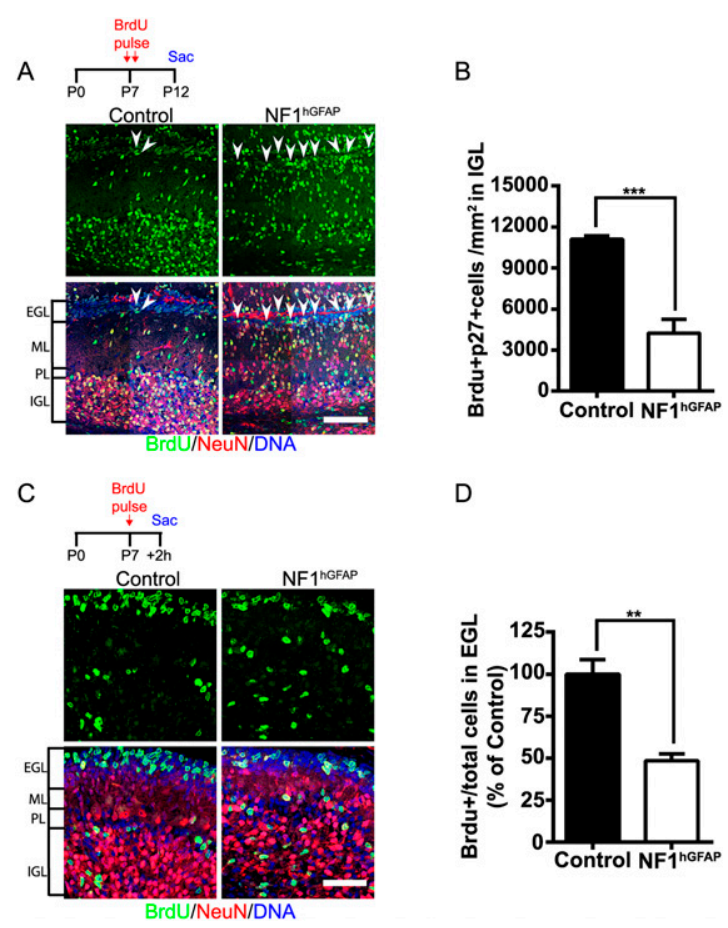

D

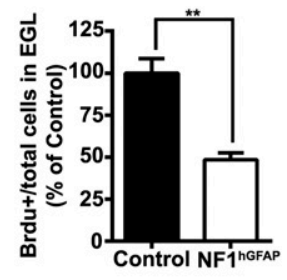

Figure 2. NF1 ablation impairs GNP migration and proliferation. (A) Tracing of granule neuron migration was assessed in control and NF1 ${ }^{\text {hGFAP }}$ mice that were pulsed with BrdU at P7 and chased until P12. Arrowheads show an increased number of BrdUpositive cells in the mutant pial surface, indicating impaired migration. Bar, $100 \mu \mathrm{m}$. (B) Quantification of a decreased number of mutant BrdU-positive cells reaching the IGL. Mean \pm SEM; $n=$ 4; $\left.\left.\right|^{\star \star \star}\right) P<0.001$. $(C)$ Decreased EGL cell proliferation in the mutant cerebellum. GNP proliferation was evaluated after a short 2-h chase following BrdU administration at P7 in control and mutant animals. Bar, $50 \mu \mathrm{m}$. $(D)$ Quantification of BrdU-positive cells among total cells in the EGL (identified with DNA staining). Mean \pm SEM; $\left.n=4 ;\left.\right|^{\star \star}\right) P<0.01$ the combined consequence of impaired GNP proliferation and migration.

\section{Postnatal NF1 ablation is sufficient to cause cerebellar abnormalities}

The major constituents of cerebellar development are GNPs, Purkinje neurons, BG, and oligodendrocytes (Hatten and Heintz 1995; Mathis et al. 2003; Buffo and Rossi 2013). In the NF1 ${ }^{\text {hGFAP }}$ mouse model, NF1 is ultimately deleted in both the glial and neuronal lineages (excluding Purkinje neurons), commencing very early in development. Thus, to better isolate the cell-autonomous role of NF1 in cerebellar GNP and BG development from astrocyte and oligodendroglial contributions, we turned to a well-characterized tamoxifen-inducible GNP-specific transgene (Nestin-CreER ${ }^{T 2}$ ) (Supplemental Fig. 2A; Chen et al. 2009; Li et al. 2012). Nestin-CreER ${ }^{T 2} ; N F 1^{\text {flox } / \text { flox }}$; Rosa26 ${ }^{\text {LacZ/YFP }}$ animals (hereafter referred to as $\mathrm{NF}^{\mathrm{Nes}}$ mice) and Rosa26 control reporter mice were administered tamoxifen at birth (P0) to induce cre-mediated recombination and then stained for 5-bromo-4-chloro-3-indolyl- $\beta$-Dgalactopyranoside (X-Gal) at P4 and P12 (Fig. 3A). At P4, $\mathrm{X}$-Gal staining in control and NF1 ${ }^{\mathrm{Nes}}$ cerebella was found primarily at the EGL and, by P12, transferred to the IGL, confirming the appropriate lineage tracing of the GNPs, although an increased number of X-Gal-positive cells remained at the mutant EGL (Fig. 3A). $\beta$-Galactosidase immunostaining confirmed the strong cre-recombinase activity at P4 that is predominantly localized to the EGL (Supplemental Fig. 2B). Immunofluorescence studies performed with P12 cerebellar sections derived from NestinCreER ${ }^{T 2}$; Rosa26 ${ }^{G F P}$ reporter mouse brains using markers for granule neurons (NeuN), Purkinje neurons (calbindin), and Bergmann/radial glia (BLBP) verified that cre activity was predominantly present in both GNPs and granule neurons as well as BG but not Purkinje cells $\left(\mathrm{GFP}^{+} \mathrm{NeuN}^{+}\right.$ cells $/ \mathrm{NeuN}^{+}$cells, 96.14\% $\pm 2.16 \%$; $\mathrm{GFP}^{+} \mathrm{BLBP}^{+}$cells/ $\mathrm{BLBP}^{+}$cells, $93.74 \% \pm 1.98 \%$ ) (Fig. 3B). Thus, granule neurons accounted for the highest proportion of crerecombinase-positive cells in the reporter mouse cerebella (among $\mathrm{GFP}^{+}$cells: $\mathrm{GFP}^{+} \mathrm{NeuN}^{+}$cells, $86.8 \% \pm 1.7 \%$; $\mathrm{GFP}^{+} \mathrm{BLBP}^{+}$cells, $11.3 \% \pm 0.3 \%$; $\mathrm{GFP}^{+}$calbindin ${ }^{+}$cells, $0.0 \%$ ). Western blot analysis further illustrated the marked reduction of NF1 protein in NF1 ${ }^{\mathrm{Nes}}$ cerebella at the ages examined (Fig. 3C). As previously mentioned, the residual NF1 protein likely comes from a combination of neurons, oligodendroglia, and afferent neuronal projections from other brain regions that do not express cre together with a small proportion of GNPs that may have escaped targeted cre recombination.

In contrast to NF1 ${ }^{\text {hGFAP }}$ mutant mice, the cortex size and olfactory bulb size were relatively unaffected in $\mathrm{NF} 1^{\mathrm{Nes}}$ mice (Fig. 3D), as also was their brain to body weight ratio (Fig. 3E). However, $\mathrm{NF}^{\mathrm{Nes}}$ animals did exhibit reduced cerebellar size by $\mathrm{P} 12$ that persisted into adulthood (Fig. 3D,F). Histological analysis further documented NF1 ${ }^{\text {Nes }}$ mutant altered cerebellar morphology at P12 that included reduced folia size, a disorganized PL, and reduced cellularity in the IGL (Fig. 3G). 
A

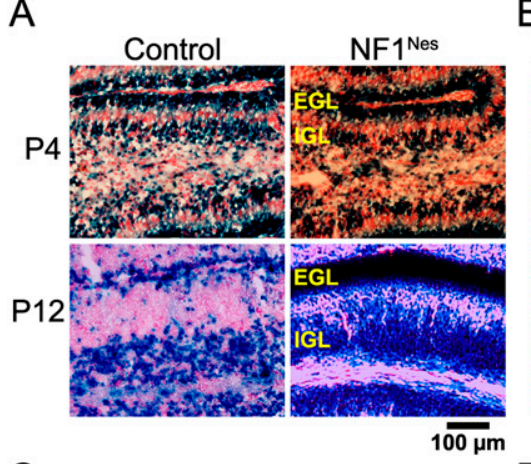

C

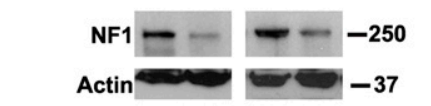

B

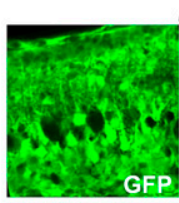
Nestin-CreER ${ }^{\text {T2 }}$ Rosa26 ${ }^{\text {GFP }}$

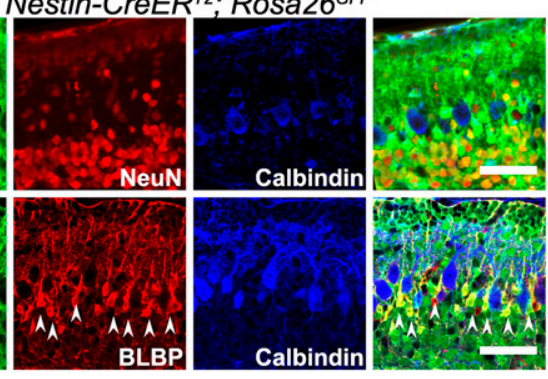

E

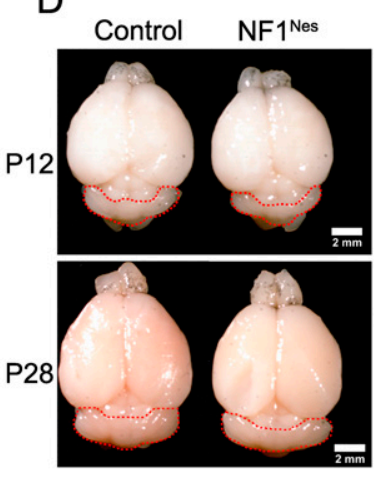

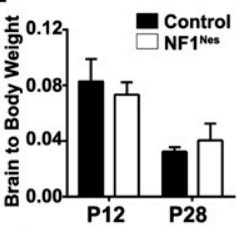

$\mathrm{F}$

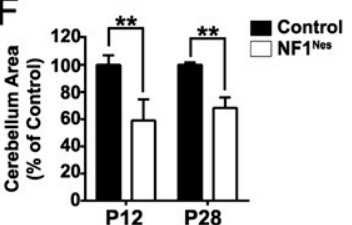

G

$\mathrm{P} 2$

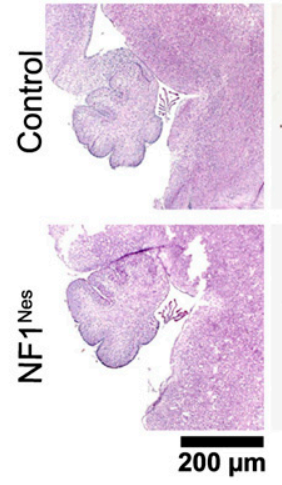

P12

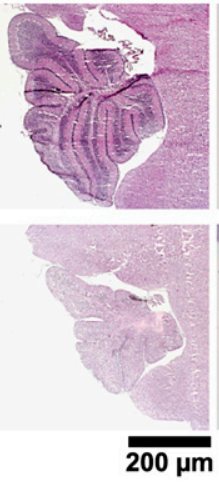

P28

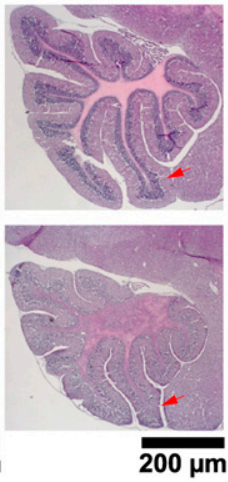

P28

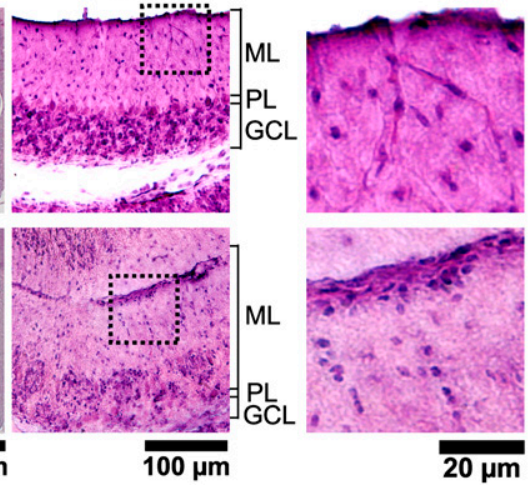

Figure 3. Postnatal NF1 loss impairs cerebellar foliation. (A) X-Gal staining to assess cre-recombinase activity in the cerebella of Rosa $26^{\text {LacZ }}$ reporter mice (control) and $\mathrm{NF}^{\mathrm{Nes}}$ animals. Tamoxifen was administered at birth (PO). (B) Immunofluorescence staining of cerebellar sections of Nestin-CreER ${ }^{T 2}$; Rosa $26^{G F P}$ reporter mice administered tamoxifen at P0 and sacrificed at P12. Antibodies to GFP (cre), NeuN (granule neuron), calbindin (Purkinje neuron), and BLBP (BG) were used to assess cre-recombinase activity in the neuronal and glial lineages. Arrowheads denote cre-expressing BG. Bar, $100 \mu \mathrm{m} .(C)$ Quantitative Western blot analysis of NF1 protein in control and mutant cerebella. Molecular weight markers (in kilodaltons) are shown. Mean \pm SEM; $n=3 ;\left(^{\star \star}\right) P<0.01$. $(D)$ Representative whole-mount images of control and NF1 ${ }^{\text {Nes }}$ brains. The mutant cerebellum appears smaller than control. Cerebella are circled by red dashed lines. (E) Analysis of brain weight to body weight ratio shows no differences between control and NF1 ${ }^{\text {Nes }}$ animals. Mean \pm SEM; $n=7$. (F) Quantitative analysis revealed a $40 \%$ reduction in cerebellar area in mutant animals at P12 that was sustained until adulthood. Mean \pm SEM; $n=6 ;\left(^{\star \star}\right) P<0.01 .(G)$ H\&E staining of control and NF1 ${ }^{\text {Nes }}$ cerebellar sections at different stages throughout postnatal development. Red arrows indicate folium III of control and mutant P28 mice. High-magnification images of folium III are shown in the adjacent right panels. Note that the mutant cerebellum has cell clusters that are retained in the pial surface, an increased number of cells in the ML (black dotted line boxes are magnified in the panels at the far right), and a disrupted PL.

Similar to NF1 ${ }^{\text {hGFAP }}$ mice, high-magnification photomicrographs showed residual cell clusters present at the pial surface in P28 NF1 ${ }^{\mathrm{Nes}}$ mice (Fig. 3G). As in the NF1 ${ }^{\text {hGFAP }}$ mice, the NF1 ${ }^{\text {Nes }}$ mutants showed misaligned Purkinje neurons within the PL and altered dendritic trees at P30 (Supplemental Fig. 2C), indicating that defects in Purkinje neurons occur as a consequence of improper GCL formation. Thus, postnatal ablation of NF1 in GNPs and BG is sufficient to bring about morphological deficits in postnatal development, although less severe than those caused by the earlier and more broad hGFAP-mediated embryonic ablation. 


\section{Postnatal NF1 ablation impairs GNP proliferation and migration}

Cerebellar expansion, GNP migration, and maturation occur postnatally (Roussel and Hatten 2011). Thus, GNPspecific NF1 ablation in $N F 1^{\mathrm{Nes}}$ mice might be expected to manifest some of the same features as NF1 ${ }^{\text {hGFAP }}$ mice. Control $\left(N F 1^{\text {flox/flox }}\right)$ and $N F 1^{\text {Nes }}$ mice were tamoxifeninduced at birth and administered BrdU at P7 with a 2-h chase. When compared with controls, the number of BrdUincorporating cells in the mutant EGL was reduced to $\sim 25 \%$ (Fig. 4A,B). In addition, immunofluorescence for Atoh1, a marker for GNPs, was performed to evaluate the number of BrdU-incorporating cells among the GNP population. This analysis revealed a reduction in the number of BrdU-positive cells among Atoh1-positive progenitors in $\mathrm{NF}^{\mathrm{Nes}}$ mice (Supplemental Fig. 3A,B). As an alternative approach, proliferation was evaluated by the expression of the proliferation marker Ki67. The $\mathrm{NF}^{\mathrm{Nes}}$ EGL exhibited a decreased number of Ki67-positive cells among the total cell population (Fig. 4C,D). In addition, RT-PCR analysis showed reduced Ki67 mRNA levels in P7 mutant cerebella (Fig. 4E).

Sonic hedgehog (Shh) is the major mitogen that promotes GNP proliferation in the developing cerebellum (Wechsler-Reya and Scott 1999). Shh, released from Purkinje neurons, induces expression of the transcription factor Gli1 (Goodrich et al. 1997), which in turn induces the cell cycle regulator cyclin D1 and the proto-oncogene MycN (Hatten and Roussel 2011; Roussel and Hatten 2011). To test whether Shh signaling is affected in NF1 ${ }^{\text {Nes }}$ mice, we performed RT-PCR analysis from cerebellar tissue lysates and evaluated the expression of several genes in this pathway. This analysis showed that while Purkinje neuron-derived Shh mRNA levels are unaltered in mutant mice, Gli1 transcript levels are decreased in the $\mathrm{NF} 1^{\mathrm{Nes}}$ mutant cerebellum at P7 and P12 (Fig. 4E). MycN, but not Cyclin D1, gene expression is also decreased in mutant animals at P7. Western blot analysis

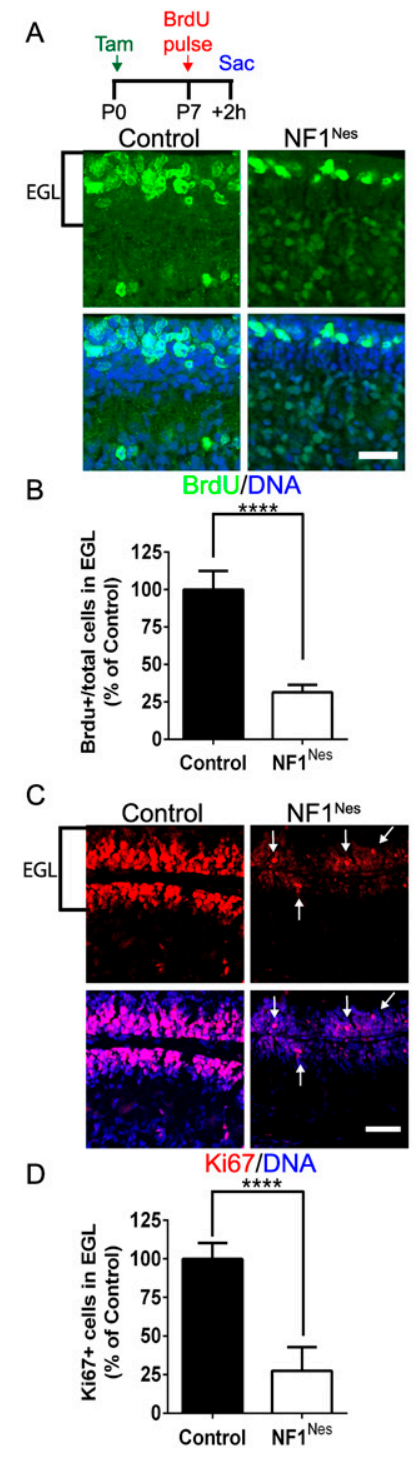

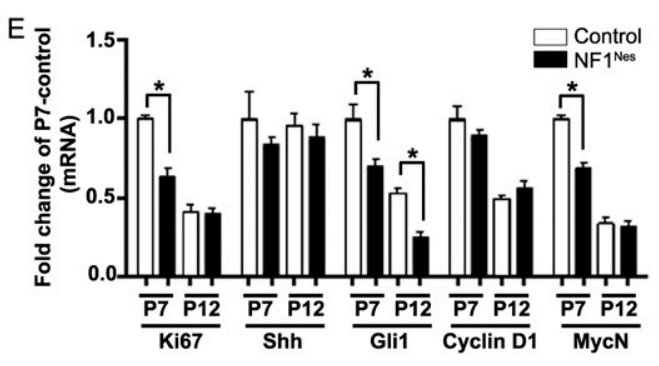

$\mathrm{F}$

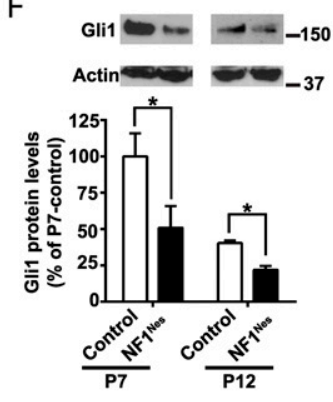

G
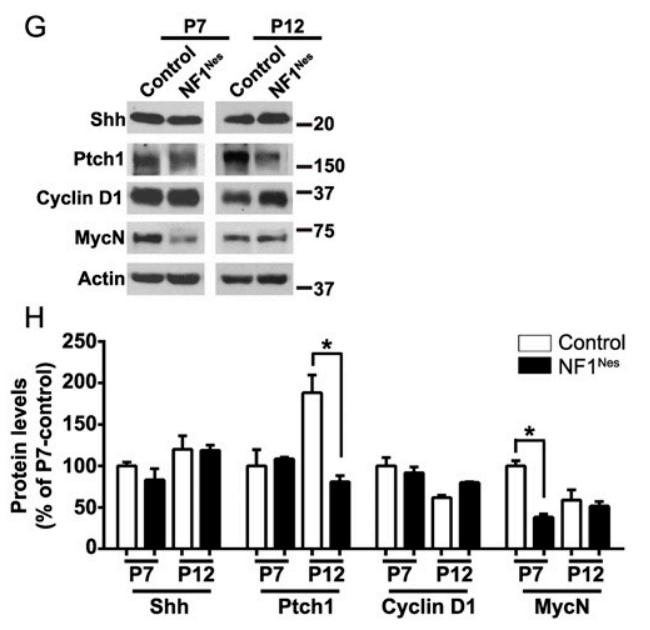

Figure 4. Defective GNP proliferation in the NF1 ${ }^{\text {Nes }}$ EGL. (A) Representative confocal images of BrdU incorporation in the EGL of control and mutant $\mathrm{P} 7$ pups that were sacrificed $2 \mathrm{~h}$ after BrdU administration. Bar, $50 \mu \mathrm{m}$. (B) Quantitative analysis revealed a decreased number of BrdU-incorporating cells among total cells in the NF1 ${ }^{\text {Nes }}$ EGL. Mean \pm SEM; $n=$ $\left.4{ }^{(\star \star \star \star}\right) P<0.0001$. (C) Assessment of progenitor cell proliferation at the EGL by Ki67 immunostaining. Arrows indicate the few Ki67-positive cells in the mutant EGL. Bar, 50 $\mu \mathrm{m}$. (D) Quantitative analysis indicated reduced Ki67 expression among the total number of cells in the NF1 ${ }^{\text {Nes }}$ EGL. Mean \pm SEM; $n=4$; $\left({ }^{\star \star \star \star}\right) P<0.0001$. $(E)$ Analysis of the transcript levels of genes involved in GNP proliferation (Ki67 and Shh signaling pathway) in control and mutant cerebella. Mean \pm SEM; $n=3 ;\left(^{\star}\right) P<$ 0.05. (F) Quantitative Western blot analysis indicating sustained reduction of Glil protein levels in NF1 ${ }^{\text {Nes }}$ cerebella. Mean \pm SEM; $n=3$; (*) $P<0.05$. (G) Representative Western blot examining the Shh signaling pathway in $\mathrm{NF}^{\text {Nes }}$ cerebella. $(H)$ Quantitative analysis indicates unaltered levels of Shh, Ptchl, and Cyclin D1 but significantly reduced levels of MycN in mutant mice at P7. Mean \pm SEM; $n=$ $3 ;\left(^{*}\right) P<0.05$. Molecular weight markers (in kilodaltons) are shown in $F$ and $G$. 
further showed reduced Gli1 protein levels in $\mathrm{NF}^{\mathrm{Nes}}$ mice (Fig. 4F). In addition, Western blotting showed decreased MycN protein levels and unaltered levels of Shh; its receptor, Ptch1; and cyclin D1 in P7 mutant mice (Fig. 4G,H). Ptch1 levels in NF1 ${ }^{\text {Nes }}$ mice were decreased at P12 (Fig. 4G,H), consistent with the reduced number of granule neurons in the mutant IGL. These results confirm that canonical GNP proliferation signaling is altered in mutant mouse cerebella despite the fact that Purkinje neuron-derived Shh availability is unaltered (Fig. 4E,G,H). Thus, it is the GNPs that are deficient in responding adequately to Shh.

To examine the migratory properties of $\mathrm{NF}^{\mathrm{Nes}} \mathrm{GNPs}$, control and mutant mice were tamoxifen-induced at birth and administered BrdU at P7 followed by a 5 -d chase (P12). We then analyzed the number of post-mitotic (p27positive) BrdU-incorporating cells in the IGL (Fig. 5A). When compared with controls, this analysis revealed a reduced number of BrdU-positive cells in the IGL of $\mathrm{NF} 1^{\mathrm{Nes}}$ mice (Fig. 5A,B). Evaluation of the ratio of BrdUpositive cells in the ML to BrdU-positive cells in the IGL confirmed that, in controls, the vast majority of BrdU cells had migrated into the IGL. While $N F 1^{\mathrm{Nes}}$ mice retained $>80 \%$ of the BrdU-positive cells in the $\mathrm{ML}$, only a relative minority of BrdU-incorporating cells reached the IGL (Fig. 5A,C). In P12 NF1 ${ }^{\text {Nes }}$ mice, BrdU-positive cells accumulated at the vestigial site of the EGL (Supplemental Fig. 3C). Thus, early NF1 loss in either the embryonic cerebellum (NF1 $1^{\text {hGFAP }}$ ) or early postnatal GNPs $\left(\mathrm{NF}^{\mathrm{Nes}}{ }^{\mathrm{N}}\right.$ ) causes severe GNP proliferative and migratory defects that contribute to a reduction of NeuN-positive granule neurons in the IGL (Fig. 5D).

In the most severe cases, 3 -wk-old NF1 ${ }^{\text {hGFAP }}$ mutant cerebella can exhibit reduced cellularity in folium IX and apparent necrosis (Supplemental Fig. 4A,B). We evaluated the level of apoptosis in control and NF1 ${ }^{\text {hGFAP }}$ animals at P10 by TUNEL staining. Mutant mice showed elevated levels of apoptosis compared with control animals (Supplemental Fig. 4C,D). Although loss of folia was not observed in $\mathrm{NF}^{\mathrm{Nes}}$ mice, these mutant cerebella also showed increased levels of apoptotic cell death at P12, as evaluated by activated caspase- 3 immunostaining (Supplemental Fig. 4E,F). Because defective migration was accompanied by apoptosis in both mutant mouse models by $\mathrm{P} 12$, these findings suggest that the primary consequence of deleting NF1 is defective cell proliferation and migration and that persistent accumulation of GNPs in the EGL and ML eventually triggers apoptotic cell death. Furthermore, the broader and earlier NF1 ablation generated in NF1 ${ }^{\text {hGFAP }}$ mutants likely causes more complex neuronal/glial interactions that cause tissue necrosis.

\section{BG abnormalities in NF1 $1^{\text {hGFAP }}$ but not $N F 1^{\text {Nes }}$ cerebella}

BG serve as critical scaffolds for inward-migrating GNPs in cerebellar development. Their cell bodies localize

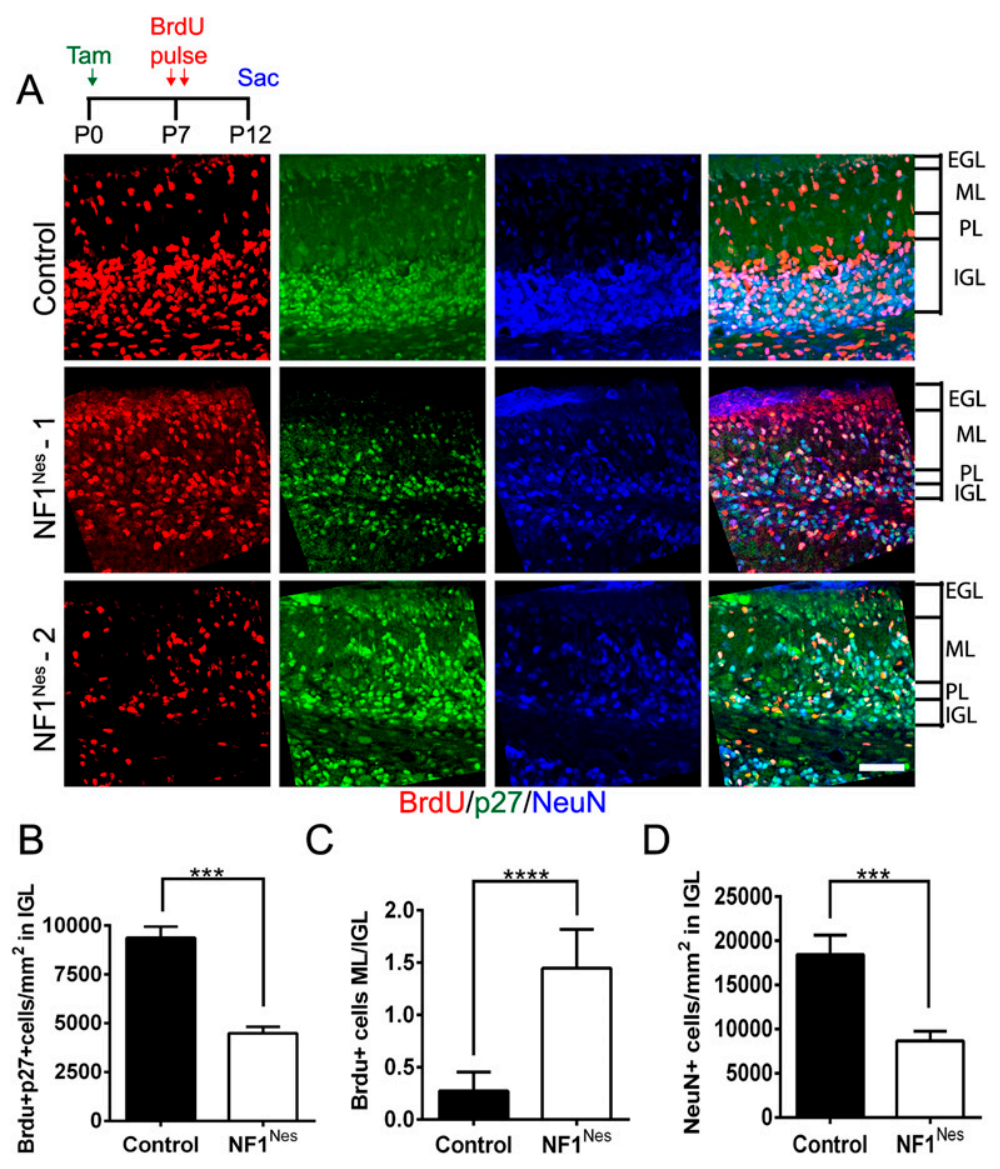

Figure 5. Neuronal migration is impaired in $\mathrm{NF}^{\mathrm{Nes}}$ mice. (A) Assessment of neuronal migration via immunostaining with BrdU, p27 (post-mitotic cell marker), and NeuN (granule neuron marker) performed $5 \mathrm{~d}(\mathrm{P} 12)$ after BrdU administration (P7). In the mutant IGL, p27 and NeuN staining show a similar disorganized pattern compared with control. Bar, $50 \mu \mathrm{m}$. $(B)$ Quantitative analysis showed a reduced number of BrdU and p27 double-positive cells in the NF1 ${ }^{\text {Nes }}$ IGL. Mean \pm SEM; $\left.n=5 i^{\star \star \star \star}\right) P<0.001 .(C) \mathrm{NF}^{\mathrm{Nes}}$ mice exhibited an increased ratio of BrdU-positive cells in the ML to BrdUpositive cells in the IGL. Mean \pm SEM; $n=5 ;\left(^{\star \star \star}\right) P<$ 0.001. (D) Reduced number of mature neurons in the mutant IGL. Mean \pm SEM; $n=5 ;\left(^{\star \star \star}\right) P<0.001$. 
adjacent to the Purkinje neurons, and they project radial fibers into the EGL to provide scaffolds for GNP migration (Chanas-Sacre et al. 2000; D'Arca et al. 2010; Xu et al. 2013). Because we observed cre-recombinase activity in BG of both mutant mouse strains, NF1 deficiency in BGs could, in principle, account for or contribute to the observed cerebellar defects, including the migration phenotype. We thus performed immunofluorescence studies with the BG markers GFAP and S100 $\beta$ in control and mutant animals. This analysis at P8 showed that NF1 ${ }^{\text {hGFAP }}$ animals have abnormal BG that contain significant numbers of fibers lacking contact with the pial surface at the EGL. These deficient fibers are thin and exhibit varicosities, and their cell bodies are misaligned within the PL, as compared with control mice (Fig. 6A). These BG abnormalities in NF1 ${ }^{\text {hGFAP }}$ mutant mice were further exacerbated by P12 (Fig. 6B). In contrast, NF1 ${ }^{\text {Nes }}$ mice appeared to have normal BG morphology at the ages examined (Fig. 6C,D). While the alignment of BG in the $\mathrm{PL}$ of the NF1 ${ }^{\mathrm{Nes}}$ cerebellum is similar to control at P12, by P21, at which time GNP migration is completed, mutant mice show misalignment of BG (Fig. 6D).

To further inspect the architecture of BG in folia, we performed immunofluorescence with anti-BLBP antibody, a lipid-binding protein that is exclusively expressed in BG and radial glia (Fig. 6E-G; Anthony et al. 2005; $\mathrm{D}^{\prime}$ Arca et al. 2010). Consistent with the aforementioned results, BLBP immunostaining showed the classical palisade of BG within the PL in control animals at P12. In NF1 ${ }^{\text {hGFAP }}$ mice, the pattern of BLBP immunostaining revealed disorganized $\mathrm{BG}$ cell bodies that were irregularly located at both the EGL and $\mathrm{ML}$, indicating an abnormal BG scaffold (Fig. 6E). The BG palisade in $\mathrm{NF}^{\mathrm{Nes}}$ mice was comparable with that of control animals at P12 (Fig. 6F). However, at P21, NF1 ${ }^{\text {Nes }}$ cerebella exhibited a defective BG scaffold (Fig. 6G). We also examined the levels of BLBP by Western blot analysis. BLBP is a direct target of Notch1 signaling, and its transcription is up-regulated in BG upon contact by migrating neurons with BG fibers (Anthony et al. 2005; D'Arca et al. 2010). Figure $6 \mathrm{H}$ shows that
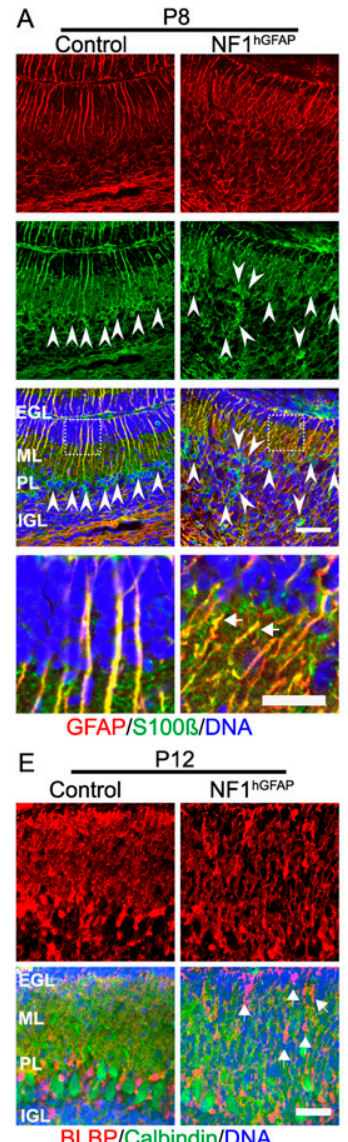

BLBP/Calbindin/DNA
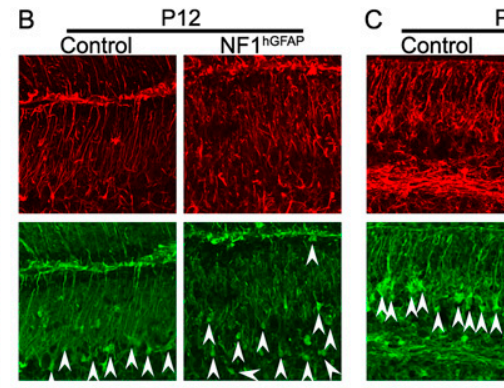

NF12
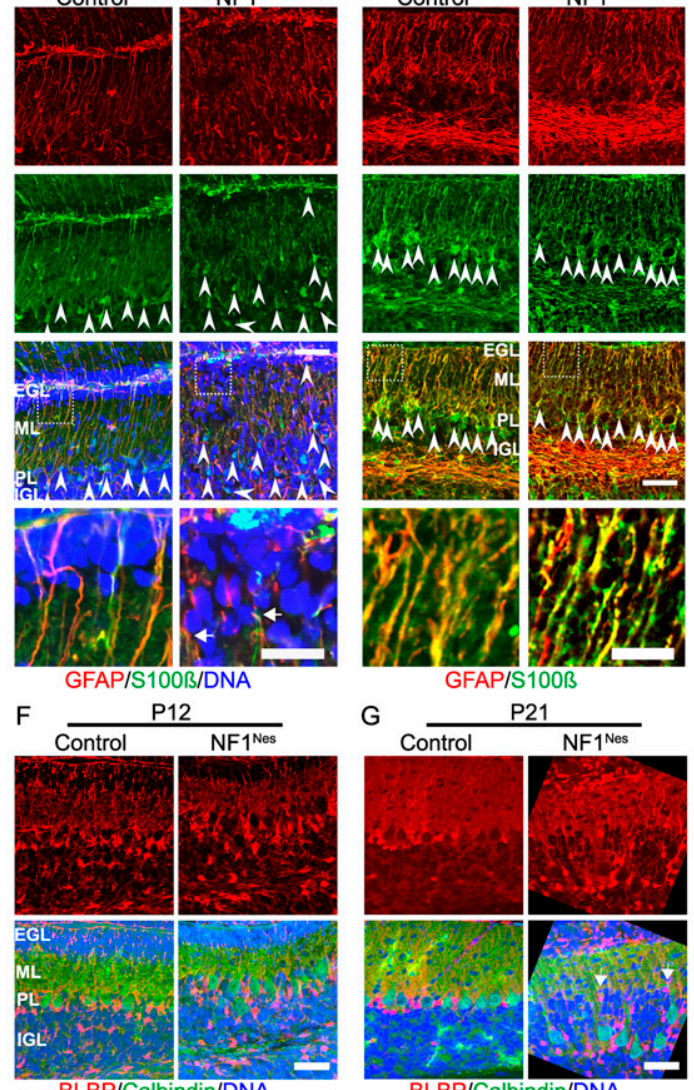

BLBP/Calbindin/DNA
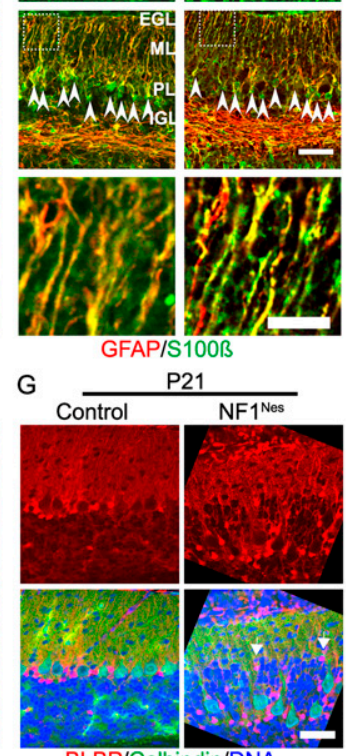

BLBP/Calbindin/DNA

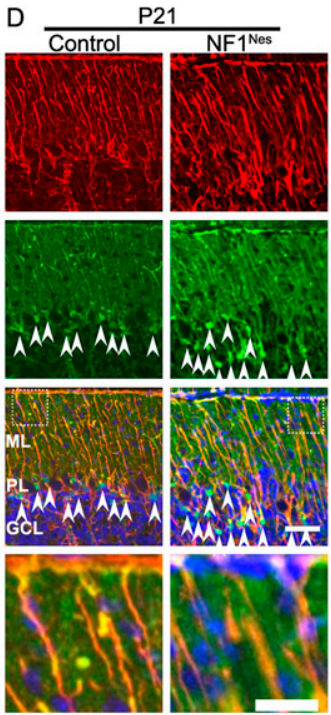

GFAPIS100ß/DNA

$\mathrm{H}$

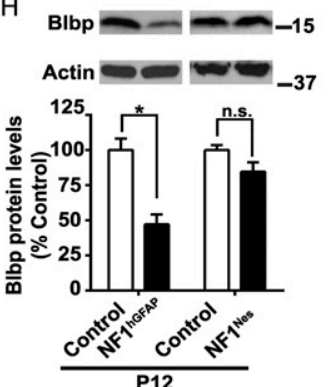

Figure 6. Defective BG in NF1 ${ }^{\text {hGFAP }}$ mice but not NF1 ${ }^{\text {Nes }}$ mice. $(A-D)$ Immunofluorescence staining with GFAP and S100 3 antibodies to identify BG fibers in control and NF1 ${ }^{\text {hGFAP }}$ cerebella at P8 $(A)$ and P12 $(B)$ and control and NF1 ${ }^{\text {Nes }}$ cerebella at P12 $(C)$ and P21 $(D)$. Arrowheads indicate the location of BG cell bodies. Dashed line boxes encompass magnified regions that are shown in the bottom panels. Arrows in the bottom panels of $A$ and $B$ indicate abnormal morphology of BG fibers in NF1 ${ }^{\text {hGFAP }}$ mice. Bars: $50 \mu \mathrm{m} ;$ bottom panels, $20 \mu \mathrm{m}$. $(E-G)$ BLBP staining to identify the BG scaffold in the cerebella of control and NF1 ${ }^{\text {hGFAP }}$ animals at P12 $(E)$ and control and NF1 ${ }^{\text {Nes }}$ mice at P12 $(F)$ and P21 $(G)$. Arrows indicate mutant BG cell bodies outside of the PL (calbindin staining). Bars, $50 \mu \mathrm{m}$. $(H)$ Western blot analysis indicates that BLBP levels are decreased in P12 NF1 ${ }^{\text {hGFAP }}$ mice. Mean \pm SEM; $n=3 ;\left(^{\star}\right) P<0.05 ;($ n.s. $)$ not statistically significant. 
while BLBP protein levels were decreased by approximately twofold in NF1 $1^{\text {hGFAP }}$ mice, no changes in BLPB expression were observed in $\mathrm{NF} 1^{\mathrm{Nes}}$ animals. Quantification of BLBP-positive cells in control and NF1 ${ }^{\text {hGFAP }}$ mice (percentage of control: control, $100.00 \% \pm 10.38 \%$; $\mathrm{NF} 1^{\text {hGFAP }}, 111.59 \% \pm 9.96 \%$ ) shows that BLBP expression down-regulation, but not a reduction in cell number, is responsible for the lower BLBP levels observed in NF1 ${ }^{\text {hGFAP }}$ mutants. These results support the preceding data and indicate that BG morphology and signaling are altered in $\mathrm{NF} 1^{\text {hGFAP }}$ mice but not appreciably in $\mathrm{NF}^{\mathrm{Nes}}$ animals during the critical period of GNP migration.

Collectively, these data support the model that the more severe cerebellar phenotype in NF1 ${ }^{\text {hGFAP }}$ mice can be linked to abnormalities caused by broad embryonic cerebellar NF1 ablation, including both BG and GNPs and possibly additional glial types. In contrast, the developmental defects observed in the $\mathrm{NF} 1^{\mathrm{Nes}}$ mice are primarily, if not exclusively, the consequence of cell-autonomous deficiency in GNPs. Thus, the misalignment of both BG and Purkinje neurons observed in $\mathrm{NF}^{\mathrm{Nes}}$ mice is the consequence of altered neuronal migration and GCL formation, whereas the altered BG morphology and signaling in NF1 ${ }^{\text {hGFAP }}$ mice is the consequence of earlier and broader cre-mediated gene ablation.

\section{NF1 inactivation in GNPs does not alter lineage differentiation}

In the SVZ, ablation of NF1 has been reported to alter lineage differentiation from predominantly neuronal to glial (Wang et al. 2012). To determine whether decreased neurogenesis at the expense of increased gliogenesis could contribute to the cerebellar phenotype observed here, lineage tracing studies were performed. After tamoxifen induction at P0, BrdU was administered to control and $\mathrm{NF} 1^{\text {Nes }}$ mice at P7 and immunofluorescence using markers for neurons (NeuN), astroglia (GFAP and S100ß), oligodendroglial progenitors (olig2), and mature oligodendrocytes (MBP) was performed in cerebellar sections after a 5 -d chase. In control mice, the vast majority ( $~ 90 \%)$ of BrdU-positive cells was also NeuN positive (Supplemental Fig. 5A,D). In contrast, the populations of BrdU-positive cells that were positive for GFAP and S100B or positive for Olig2 or MBP accounted for $\sim 10 \%$ of the total number of the BrdU-positive cells (Supplemental Fig. 5B-D). Although $N F 1^{\text {Nes }}$ mice exhibited an increased number of NeuN-positive cells among BrdU-incorporating cells in the ML (Supplemental Fig. 5A), the overall lineage marker distribution among the BrdU-incorporating cells remained similar to control (Supplemental Fig. 5A-D). Comparable results were observed when BrdU was administered at P1 (Supplemental Fig. 5F-I), indicating that terminal differentiation is not altered by NF1 ablation. In addition, RT-PCR analysis of whole cerebellar tissue lysates showed decreased transcript levels of the immature neuronal marker doublecortin (Dcx) and NeuN, but not $\mathrm{S} 100 \beta$, in $\mathrm{NF}^{\mathrm{Nes}}$ mice (Supplemental Fig. S5E), demonstrating that neurogenesis, but not gliogenesis, is impaired. Together, these data indicate that the proliferation impairment in GNPs results in reduced neurogenesis that is coupled with the GNP migration defect, resulting in aberrant neuronal differentiation in the ML. These defects in GNPs ultimately culminate in reduced cerebellar size and abnormal folia layering. In all, these results strongly support the notion that NF1 regulates proliferation and migration of GNPs in the cerebellum.

\section{MAPK signaling underlies the cerebellar phenotype}

NF1 negatively regulates the RAS/ERK and PI3K/AKT signaling pathways (Klesse and Parada 1998; Hegedus et al. 2007; Lee et al. 2010). Our laboratory had previously demonstrated that the ERK, but not AKT, pathway is constitutively activated in the cortex of NF1 ${ }^{\text {hGFAP }}$ mice (Lush et al. 2008). Thus, we tested whether these pathways are activated in the cerebellum of the NF1 mutant mouse lines. Similar to the cortex, the ERK, but not AKT, pathway is activated in NF1 ${ }^{\text {hGFAP }}$ mouse cerebella, as shown by immunohistochemistry (Fig. 7A). Likewise, Western blot analysis showed increased p-ERK levels in the $N F 1^{\text {Nes }}$ mouse line cerebella, indicating its aberrant activation (Fig. 7B,C). In addition, analysis of ERK pathway downstream targets by Western blotting showed elevated levels of p-ELK and p-CREB but not p-p90RSK (Fig. 7D,E). To test whether inhibition of the ERK pathway rescues the cerebellar deficiencies observed in the NF1 mutant mouse lines, we performed two different experimental protocols for administration of an inhibitor of MEK1/2 (U0126). U0126 blocks phosphorylation and activation of ERK1/2 (Shukla et al. 2007). Control and NF1 ${ }^{\text {hGFAP }}$ animals were subjected to either perinatal (from P1 to P9) or post-GNP proliferation (from P11 to P20) U0126 administration and analyzed by histology at P21 (Fig. 7F). Perinatal inhibitor treatment in NF1 hGFAP mice effectively rescued the cerebellar structure abnormality, as the morphology was comparable with control animals (Fig. 7G). Western blot analysis confirmed U0126-induced inhibition of ERK phosphorylation and showed the reduction of aberrant ELK and CREB phosphorylation in mutant cerebella (Supplemental Fig. 6AD). In several cases, however, only a partial structural rescue of the cerebellum was observed, likely due to ineffective U0126 delivery (Fig. 7G; Supplemental Fig. $6 \mathrm{E})$. In contrast, when using the post-GNP proliferation U0126 regime (P11-P20), no morphological rescue was observed (Fig. 7H). Immunohistochemical analysis using antibodies for GABAAR $\alpha 6$, the ERK downstream target Erg-1, and GFAP showed that U0126 treatment in NF $1^{\text {hGFAP }}$ is able to achieve a partial to complete restoration of the GCL structure, Erg-1 basal levels, and gliosis, respectively (Supplemental Fig. 6F). Perinatal U0126 administration also effectively restored the cerebellar abnormalities in $\mathrm{NF}^{\mathrm{Nes}}$ mice, as the folia layering (Fig. 7I) and the overall size of the cerebellum (Fig. 7J,K; Supplemental Fig. 7A,B) were similar to control animals. Additionally, inhibitor treatment in NF1 ${ }^{\mathrm{Nes}}$ mice completely reversed the defective GNP proliferation (Supplemental Fig. 7C,D) and migration (Supplemental Fig. 7E,F) phenotypes. Consistent with the phenotypic rescue, deficient Glil and 


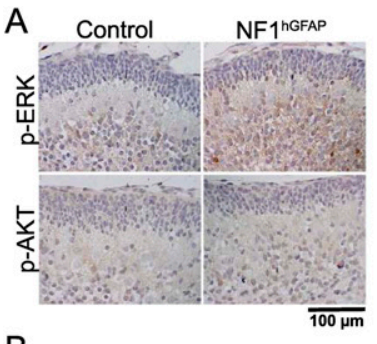

B

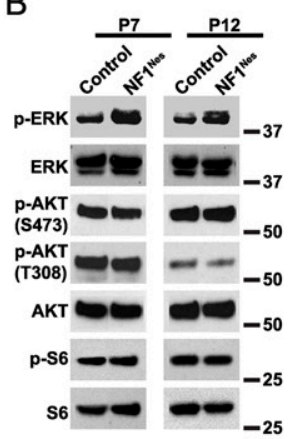

C
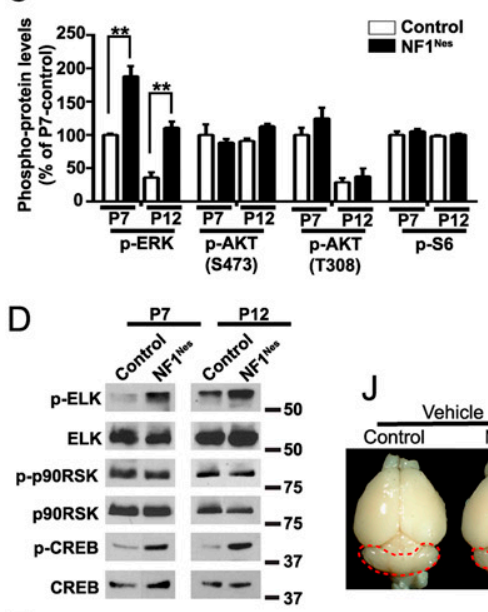

$\mathrm{E}$

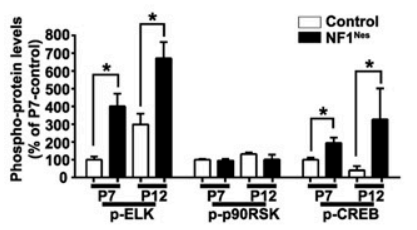

F

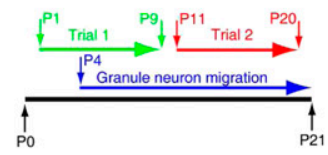

G

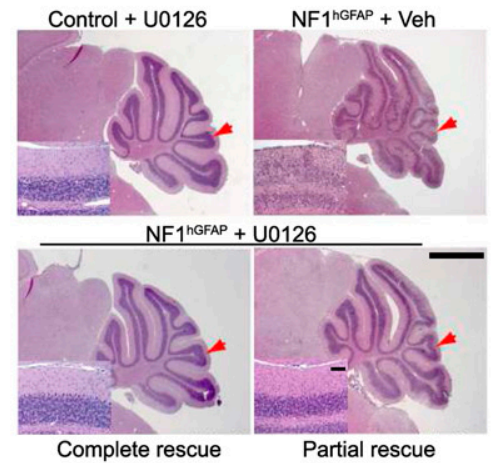

$\mathrm{H}$
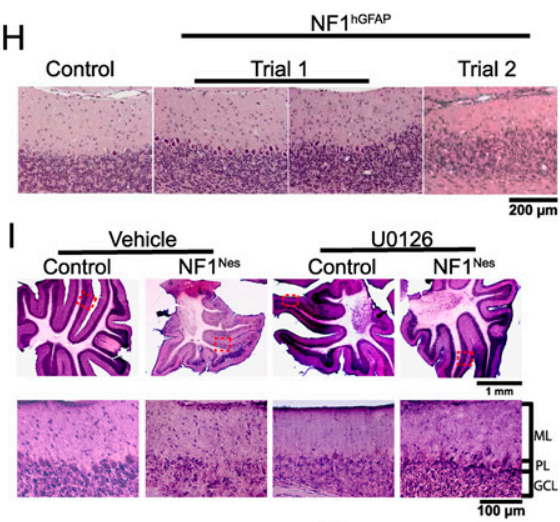

$\mathrm{K}$
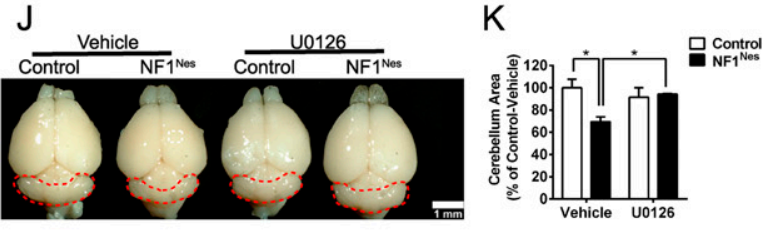

Figure 7. Postnatal pharmacological inhibition of the ERK pathway prevents cerebellar abnormalities caused by NF1 loss. (A) P2 control and NF1 ${ }^{\text {hGFAP }}$ cerebella stained with p-ERK and p-AKT (S473) antibodies. (B) Representative Western blot examining ERK and AKT phosphorylation in NF1 ${ }^{\text {Nes }}$ cerebellum whole lysates. $(C)$ Quantitative analysis indicates elevated p-ERK levels in mutant mice. Mean \pm SEM; $n=3$; $\left.{ }^{\star \star}\right) P<0.01 .(D, E)$ Quantitative Western blot analysis of ERK pathway downstream targets in NF1 ${ }^{\mathrm{Nes}}$ cerebella. Mean \pm SEM; $n=3$; $\left(^{\star}\right) P<0.05$. $(F)$ Schematic of the U0126 administration protocols used for treatment of control and mutant animals. Trial 1 was performed perinatally, while trial 2 was performed after GNPs had completed proliferative expansion. $(G)$ Cerebellar morphology analysis by H\&E staining in control and NF1 $1^{\text {hGFAP }}$ mice subjected to trial 1 of U0126 administration. Control mice treated with U0126 or vehicle showed similar cerebellar gross morphology. Red arrows indicate folium VII. Insets show folium VII layering. Bar: $1 \mathrm{~mm}$; insets, 100 $\mu \mathrm{m}$. $(H)$ Cerebellar structural defects in NF1 $1^{\text {hGFAP }}$ mice subjected to trial 2 of U0126 administration. $(I-K)$ Trial 1 paradigm U0126 administration ameliorates folia layering abnormalities in NF1 ${ }^{\mathrm{Nes}}$ cerebellum. The bottom panels show high-magnification images of regions encompassed by dashed lines. $(J, K)$ Analysis of overall cerebellar size shows restoration of mutant cerebella by U0126 treatment. Mean \pm SEM; $n=3 ;\left(^{\star}\right) P<0.05 .(L, M)$ Quantitative Western blot examination indicates normal Glil and $\mathrm{MycN}$ protein levels in U0126-treated NF1 ${ }^{\text {Nes }}$ cerebella at P7. Mean \pm SEM; $n=3$; $\left(^{\star}\right) P<0.05 ;\left(^{\star \star}\right)$ $P<0.01$. Molecular weight markers (in kilodaltons) are shown in $B, D$, and $L$.

MycN protein levels in $\mathrm{NF}^{\mathrm{Nes}}$ mice were restored to control levels by inhibitor administration (Fig. 7L,M), suggesting that NF1/ERK signaling may regulate $\mathrm{SHH} /$ PTCH signaling in perinatal GNPs.

To complement our in vivo studies, we generated GNP cultures derived from $N F 1^{\text {flox/flox }}$ mice to test whether their proliferation is NF1/ERK signaling-dependent in vitro. Cultured GNPs were transduced with adenovirus expressing either GFP (control GNPs) or cre-recombinase fused to GFP (NF1-depleted GNPs), and cells were then treated with vehicle or U0126 for $24 \mathrm{~h}$. BrdU was administered to cells for $2 \mathrm{~h}$ to analyze the number of BrdU-incorporating cells. NF1-depleted GNPs exhibited lower BrdU incorporation than control GNPs, which was effectively restored by U0126 treatment (Supplemental Fig. 8A,B). Western blot analysis demonstrated increased ERK phosphorylation in vehicle-treated NF1-depleted GNPs that was inhibited upon U0126 administration (Supplemental Fig. 8C). High levels of adenovirus transduction efficiency were achieved in GNP cultures (Supplemental Fig. 8D), resulting in efficient cre-mediated NF1 recombination (Supplemental Fig. 8E). These results reiterate that cell-autonomous deficiencies in GNPs, which are strictly MEK-dependent, results in cerebellar malformation in $\mathrm{NF} 1^{\mathrm{Nes}}$ mutants.

In addition to developing cerebellar deficits, NF1 ${ }^{\text {hGFAP }}$ animals have a deficiency in somatosensory cortical barrel formation that is accompanied by elevated p-ERK 
levels (Lush et al. 2008). Cortical barrel formation is triggered by the innervation of thalamic axons into cortical layer IV of the somatosensory cortex, where neurons are instructed to form rings (termed barrels) around the incoming axons (Li and Crair 2011). We sought to determine whether postnatal pharmacological ERK inhibition could also rescue the barrel cortex structural deficiency. U0126 or vehicle was administered daily in control and mutant mice, and, at P8, animals were analyzed for the presence of cortical barrels. U0126 administration to NF1 ${ }^{\text {hGFAP }}$ animals resulted in a partial to complete restoration of the cortical barrels (Supplemental Fig. 9A,B), re-establishing the ring-like nucleus distribution that was completely absent (Supplemental Fig. 9B,C). Western blot analysis showed the U0126induced inhibition of phosphorylated ERK and its downstream target, ELK, in NF1 ${ }^{\text {hGFAP }}$ animals (Supplemental Fig. 9D,E). These results show an equivalent reversion of the barrel cortex structural defect by U0126 administration and that cortical barrel formation is NF1/ERK signaling-dependent. Taken together, these data indicate that ERK signaling is critical in postnatal development of cortical barrels and cerebellar folia and indicate a therapeutic window of opportunity in which NF1-mediated cerebellar deficits can be ameliorated. This window of opportunity coincides with when GNPs are massively proliferating and migrating in the cerebellum.

\section{Discussion}

The cerebellum has well-established and characterized functions in motor coordination and learning (Steinlin 2008; Hatten and Roussel 2011). Syndromes such as ataxia are most commonly attributed to deficiencies in this structure (Steinlin 2008; Basson and Wingate 2013). However, more recent human imaging and cerebellar injury studies have broadened the scope of cerebellar function to include aspects of cognition, associative learning, emotional response, and behavior (Timmann et al. 2010). Indeed, studies of ASD have also reported links with abnormal cerebellar anatomy or function (Courchesne et al. 2011; Skefos et al. 2014). Mouse models of both of the tuberous sclerosis complex (TSC1 and TSC2) genes have further molecularly linked the function of these genes and the signaling pathways that they regulate with autism-like behaviors and cerebellar deficiencies (Tsai et al. 2012; Reith et al. 2013). It has long been appreciated that individuals with Neurofibromatosis type 1, caused by germline mutation of the NF1 tumor suppressor, are at high risk for intellectual and/or cognitive deficits (Costa and Silva 2003; Hyman et al. 2005; Samuels et al. 2009). In the past, many of these claims have remained largely anecdotal; however, recent concerted efforts have confirmed these findings (Lorenzo et al. 2013; Costa et al. 2014) and revealed a high incidence of ASD among NF1 individuals (Garg et al. 2013).

Numerous studies using mouse models have shown important roles for NF1 in diverse but specific aspects of CNS development and function. NF1 inactivation in the embryonic cortex results in disruption of the thalamocortical circuitry, permitting thalamic projections into the somatosensory cortex but disrupting proper barrel formation (Lush et al. 2008). Thus, cellautonomous NF1 loss affects paracrine interactions with thalamocortical inputs. Cui et al. (2008) reported that telencephalic deletion of NF1 during embryonic development disrupted GABAA neurotransmitter release and impaired learning. Depletion of NF1 in adult subgranular zone (SGZ) stem cells enhanced hippocampal neurogenesis that modulated and improved depressive-like behaviors in mice (Li et al. 2012). Finally, NF1 inactivation in adult SVZ stem/progenitor cells altered the glia/neuron fate specification by promoting Olig2 expression (Wang et al. 2012). Therefore, in distinct brain regions, NF1 loss in neurons or stem cells resulted in abnormal cell-to-cell communication, neurotransmitter signaling, neurogenesis, or cell fate specification.

Champion et al. (2014) recently reported on the comorbidity of motor skills and cognition in children with neurofibromatosis. Whether this observation can be directly ascribed to cerebellar function was not assessed. The present study reveals a profound disruption of cerebellar organization when NF1 is deleted in progenitor cell populations, leading to additional (to those enumerated above) cell-autonomous phenotypes for NF1 in the CNS. These include BG alignment and morphology, disrupted migration of GNPs, and disrupted proliferation of GNPs. We used two different cre-recombinase-expressing transgenes to probe NF1 function. The hGFAP-cre transgene promoted recombination early in CNS embryogenesis and caused NF1 ablation in the precursor cells of cerebellar progenitors, $\mathrm{BG}$, and associated astrocytes as well as in cortical barrel-forming neurons. The consequences of this broad and early NF1 deletion was a severely malformed cerebellum that likely resulted from abnormal functions in each of the diverse cell types affected, since each exhibited morphological defects. In particular, there was evidence of reactive astrogliosis, misaligned and inadequately projected BG, and abnormal localization of granule cells at the ML. A second cre-expressing transgene, Nestin-cre $e^{E R T 2}$, was subjected to tamoxifen-induced activation at birth (PO) and confined NF1 loss to neonatal cerebellum, specifically to GNPs in the EGL and, to a lesser extent, BG. These mice also developed gross anatomical abnormalities, although less severe and resulting specifically from NF1 loss in GNPs. The NF1-deficient BG, whose extensions from the PL to the EGL had formed prior to P0 tamoxifen induction, appeared structurally normal in these mice. The unique mature architecture of the mammalian cerebellum is achieved by a choreographed migration and interplay of EGL-generated GNPs through the PL to colonize and form the IGL, at whose outer borders are found the cell bodies of BG and of the Purkinje cells. The $\mathrm{NF}^{\mathrm{Nes}}$ mutant mice had cerebellar malformations characterized by reduced and inappropriately localized granule neurons in addition to a disrupted PL. The developmental analysis indicates that, contrary to the NF1 ${ }^{\text {hGFAP }}$ mutant mice, the NF1 ${ }^{\text {Nes }}$ phenotype could be ascribed to deficiencies in GNP proliferation and migration. The 
misalignment of the PL was a secondary effect of the abnormal GNP behavior. We anticipated that the cerebellar lesions caused by NF1 mutations by both transgenes used in the present study would result in significant behavioral phenotypes. However, both of the cre transgenes exhibit expression in additional brain regions (notably, the SVZ and SGZ as well as telencephalon in the case of $h G F A P$-crel, thus rendering the interpretability of behavioral studies inadequate. Indeed, we extended our findings in the cerebellum to the somatosensory cortex development, whose cortical barrel formation is also compromised in NF1 ${ }^{\text {hGFAP }}$ mice (Lush et al. 2008). We confirmed our previous report that the RAS/ERK pathway is abnormally active and, by analogy to the cerebellum studies, that pharmacological MEK inhibition can also reverse these defects.

Neurofibromin is a RAS GAP that regulates both the AKT and ERK pathways (Cichowski and Jacks 2001; Zhu et al. 2001). A common theme in studies of NF1 in the brain is the constitutive activation of the ERK pathway, but not the AKT pathway, as a function of NF1 ablation (Lush et al. 2008; Li et al. 2012; Wang et al. 2012). This has prompted the use of specific ERK inhibitors to successfully treat NF1 mutant animals in the effort to restore normal forebrain development (Li et al. 2012; Wang et al. 2012) or counteract NF1 loss-mediated tumor development (Chang et al. 2013; Jessen et al. 2013; Staser et al. 2013; Nissan et al. 2014).

In mouse models, directed NF1 loss in embryonic cerebellar precursors, cortical progenitors, or neonatal GNPs can cause severe structural malformations. This fact emphasizes how, in the setting of heterozygous germline NF1 mutation in humans, spontaneous and isolated NF1 loss of heterozygosity (LOH) during cerebellar or cortical development could generate morphologically subtle, localized anatomical abnormalities that may underlay cognitive and behavioral sequelae. We were surprised and encouraged by the dramatic effects of a first-generation ERK pathway inhibitor (U0126) administered after birth in reversing substantially the anatomical deficits in GNP proliferation and migration as well as cortical barrel formation, even when the NF1 mutation occurred in embryonic development. These data provide a proof of principle that, as we better understand the role of cerebellar and cortical malfunction in Neurofibromatosis type 1, neonatal treatment with advanced ERK pathway inhibitors may provide a significant means of counteracting cognitive and motor inadequacies.

\section{Materials and methods}

\section{Animals}

NF1 flox/flox, hGFAP-cre, and Nestin-CreER ${ }^{T 2}$ lines were generated as described (Zhu et al. 2001; Zhuo et al. 2001; Chen et al. 2009). NF1 flox/flox,$N F 1^{\text {flox/+ }}$, and NF1 flox/+ ; hGFAP-Cre were phenotypically undistinguishable and used as controls. For inducible experiments, tamoxifen-treated $N F 1^{\text {flox/flox }}, N F 1^{\text {flox } /+}$, and $\mathrm{NF}^{\text {flox/+ }}$; Nestin-CreER ${ }^{\mathrm{T2}}$ animals served as controls. All mouse manipulations were performed in accordance with protocols approved by the Institutional Animal Care and Research Advisory Committee at University of Texas Southwestern Medical Center.

Detailed descriptions of the animals, GNP culture generation, tissue preparation for histological analysis and quantifications, $\beta$-galactosidase staining, evaluation of apoptosis, and RT-qPCR and Western blot analyses are included in the Supplemental Material.

\section{Tamoxifen administration}

The estrogen analog tamoxifen (Sigma) was dissolved in a sunflower oil/ethanol mixture $(9: 1)$ at $20 \mathrm{mg} / \mathrm{mL}$. Control and $\mathrm{NF}^{\mathrm{Nes}}$ animals were administered tamoxifen at birth (P0) through a single subcutaneous injection at a dosage of $350 \mathrm{mg}$ per kilogram of body weight.

\section{Histology and immunohistochemistry}

$\mathrm{H} \& \mathrm{E}$ staining was performed in paraffin-embedded or frozen sections. For immunohistochemistry, vibratome sections were blocked in 5\% normal donkey serum prepared in PBS and 0.3\% TritonX-100 for $1 \mathrm{~h}$. Sections were incubated overnight at $4^{\circ} \mathrm{C}$ with the following primary antibodies: GFP (1:500; Rockland); S100ß (1:500; Sigma); GFAP (1:400; DAKO); Ki67 (1:400; Thermo); calbindin, GABAAR $\alpha 6$, and BrdU (1:400; Abcam); BLBP (1:2000; Abcam); NeuN, MBP, and Olig2 (1:400; Millipore); p-ERK and p-AKT (1:200; Cell Signaling); and p27 and Erg-1 (1:200; Santa Cruz Biotechnology). Primary antibodies were visualized with Cy2-, Cy3-, or Cy5-conjugated secondary antibodies 1:500; Jackson ImmunoResearch). Nuclear counterstaining was performed with $1 \mu \mathrm{g} / \mathrm{mL}$ DAPI. Paraffin-embedded sections were incubated with biotinylated secondary antibodies, followed by signal amplification and visualization with the avidin-biotin complex (ABC) system and DAB substrate (Vector Laboratories).

\section{BrdU pulse chase assays}

BrdU was administered into neonatal mice subcutaneously at a dosage of $200 \mu \mathrm{g}$ per gram of body weight. Multiple BrdU pulses were performed at 2 -h intervals. For analysis of cell proliferation, P7 mice were perfused $2 \mathrm{~h}$ after a single BrdU pulse. For the analysis of neuronal migration, animals were pulsed twice at P7 and sacrificed $120 \mathrm{~h}$ after the initial pulse. For lineage tracing analyses, mice were pulsed twice with BrdU at either P1 or P7 and perfused 264 or $120 \mathrm{~h}$ after the initial pulse (P12), respectively. BrdU incorporation was assessed in vibratome or frozen sections that were incubated with $2 \mathrm{M} \mathrm{HCl}$ for $2 \mathrm{~h}$, transferred to $0.1 \mathrm{M}$ sodium borate ( $\mathrm{pH} 8.5$ ) for $20 \mathrm{~min}$, and subjected to antiBrdU fluorescence immunohistochemistry.

\section{MEK1/2 inhibitor treatment}

Treatment of animals with the MEK1/2 inhibitor U0126 (Cell Signaling) was performed as described (Shukla et al. 2007). For 10 $\mathrm{mM}$ stock, $5 \mathrm{mg}$ of U0126 was dissolved into $0.655 \mathrm{~mL}$ of DMSO and $0.655 \mathrm{~mL}$ of PBS (1.31-mL total volume), and aliquots were prepared and stored at $-20^{\circ} \mathrm{C}$. For experiments, the stock solution was further diluted 10 times with water. A daily dose of $5 \mathrm{mg}$ of U0126 per kilogram of body weight was administered subcutaneously as indicated in Figure 7F. Injection of vehicle consisting of $5 \%$ DMSO in PBS served as control.

\section{Statistical analyses}

Student's $t$-tests were used to determine statistical differences in data with two groups of samples. One-way ANOVA analyses 
were used for data comparisons of more than two groups and were followed by Tukey's-Kramer post hoc test for significance. A value of $P<0.05$ was deemed statistically significant. Data were analyzed using GraphPad Prism, version 6.02 (GraphPad Software).

\section{Acknowledgments}

We thank Yuan Zhu for early discussions and sharing of data. We thank Yanjiao Li, Tracey Shipman, and Chen Zhang for technical assistance. We also thank all members of the Parada laboratory for helpful ideas and insightful discussions. This work was supported by National Institutes of Health grant P50 (to L.F.P.) and the Simons Foundation. L.F.P. is an American Cancer Society Research Professor.

\section{References}

Alder J, Cho NK, Hatten ME. 1996. Embryonic precursor cells from the rhombic lip are specified to a cerebellar granule neuron identity. Neuron 17: 389-399.

Anthony TE, Mason HA, Gridley T, Fishell G, Heintz N. 2005. Brain lipid-binding protein is a direct target of Notch signaling in radial glial cells. Genes Dev 19: 1028-1033.

Balestri P, Vivarelli R, Grosso S, Santori L, Farnetani MA, Galluzzi P, Vatti GP, Calabrese F, Morgese G. 2003. Malformations of cortical development in neurofibromatosis type 1. Neurology 61: 1799-1801.

Basson MA, Wingate RJ. 2013. Congenital hypoplasia of the cerebellum: developmental causes and behavioral consequences. Front Neuroanat 7: 29.

Buffo A, Rossi F. 2013. Origin, lineage and function of cerebellar glia. Prog Neurobiol 109: 42-63.

Champion JA, Rose KJ, Payne JM, Burns J, North KN. 2014. Relationship between cognitive dysfunction, gait, and motor impairment in children and adolescents with neurofibromatosis type 1. Dev Med Child Neuro 56: 468-474

Chanas-Sacre G, Rogister B, Moonen G, Leprince P. 2000. Radial glia phenotype: origin, regulation, and transdifferentiation. $I$ Neurosci Res 61: 357-363.

Chang T, Krisman K, Theobald EH, Xu J, Akutagawa J, Lauchle JO, Kogan S, Braun BS, Shannon K. 2013. Sustained MEK inhibition abrogates myeloproliferative disease in NF1 mutant mice. J Clin Invest 123: 335-339.

Chen J, Kwon CH, Lin L, Li Y, Parada LF. 2009. Inducible sitespecific recombination in neural stem/progenitor cells. Genesis 47: 122-131.

Cichowski K, Jacks T. 2001. NF1 tumor suppressor gene function: narrowing the GAP. Cell 104: 593-604.

Costa RM, Silva AJ. 2003. Mouse models of neurofibromatosis type I: bridging the GAP. Trends Mol Med 9: 19-23.

Costa DD, de Paula JJ, de Rezende NA, Rodrigues LO, MalloyDiniz LF, Romano-Silva MA, Miranda DM. 2014. Neuropsychological impairments in elderly Neurofibromatosis type 1 patients. Eur J Med Genet 57: 216-219.

Courchesne E, Campbell K, Solso S. 2011. Brain growth across the life span in autism: age-specific changes in anatomical pathology. Brain Res 1380: 138-145.

Cui Y, Costa RM, Murphy GG, Elgersma Y, Zhu Y, Gutmann DH, Parada LF, Mody I, Silva AJ. 2008. Neurofibromin regulation of ERK signaling modulates GABA release and learning. Cell 135: 549-560.

D'Arca D, Zhao X, Xu W, Ramirez-Martinez NC, Iavarone A, Lasorella A. 2010. Huwe1 ubiquitin ligase is essential to synchronize neuronal and glial differentiation in the developing cerebellum. Proc Natl Acad Sci 107: 5875-5880.
Garg S, Green J, Leadbitter K, Emsley R, Lehtonen A, Evans DG, Huson SM. 2013. Neurofibromatosis type 1 and autism spectrum disorder. Pediatrics 132: e1642-1648.

Goodrich LV, Milenković L, Higgins KM, Scott MP. 1997. Altered neural cell fates and medulloblastoma in mouse patched mutants. Science 277: 1109-1113.

Hatten ME, Heintz N. 1995. Mechanisms of neural patterning and specification in the developing cerebellum. Annu Rev Neurosci 18: 385-408.

Hatten ME, Roussel MF. 2011. Development and cancer of the cerebellum. Trends Neurosci 34: 134-142.

Hegedus B, Dasgupta B, Shin JE, Emnett RJ, Hart-Mahon EK, Elghazi L, Bernal-Mizrachi E, Gutmann DH. 2007. Neurofibromatosis-1 regulates neuronal and glial cell differentiation from neuroglial progenitors in vivo by both cAMP- and Rasdependent mechanisms. Cell Stem Cell 1: 443-457.

Hyman SL, Shores A, North KN. 2005. The nature and frequency of cognitive deficits in children with neurofibromatosis type 1. Neurology 65: 1037-1044.

Jessen WJ, Miller SJ, Jousma E, Wu J, Rizvi TA, Brundage ME, Eaves D, Widemann B, Kim MO, Dombi E, et al. 2013. MEK inhibition exhibits efficacy in human and mouse neurofibromatosis tumors. J Clin Invest 123: 340-347.

Klesse LJ, Parada LF. 1998. p21 ras and phosphatidylinositol-3 kinase are required for survival of wild-type and NF1 mutant sensory neurons. J Neurosci 18: 10420-10428.

Lee DY, Yeh TH, Emnett RJ, White CR, Gutmann DH. 2010. Neurofibromatosis-1 regulates neuroglial progenitor proliferation and glial differentiation in a brain region-specific manner. Genes Dev 24: 2317-2329.

Li H, Crair MC. 2011. How do barrels form in somatosensory cortex? Ann N Y Acad Sci 1225: 119-129.

Li Y, Luikart BW, Birnbaum S, Chen J, Kwon CH, Kernie SG, Bassel-Duby R, Parada LF. 2008. TrkB regulates hippocampal neurogenesis and governs sensitivity to antidepressive treatment. Neuron 59: 399-412.

Li Y, Li Y, McKay RM, Riethmacher D, Parada LF. 2012. Neurofibromin modulates adult hippocampal neurogenesis and behavioral effects of antidepressants. I Neurosci 32: 3529-3539.

Lorenzo J, Barton B, Arnold SS, North KN. 2013. Cognitive features that distinguish preschool-age children with neurofibromatosis type 1 from their peers: a matched case-control study. Pediatrics 163: 1479-1483 e1471.

Luikart BW, Nef S, Virmani T, Lush ME, Liu Y, Kavalali ET, Parada LF. 2005. TrkB has a cell-autonomous role in the establishment of hippocampal Schaffer collateral synapses. I Neurosci 25: 3774-3786.

Lush ME, Li Y, Kwon CH, Chen J, Parada LF. 2008. Neurofibromin is required for barrel formation in the mouse somatosensory cortex. J Neurosci 28: 1580-1587.

Marui T, Hashimoto O, Nanba E, Kato C, Tochigi M, Umekage T, Ishijima M, Kohda K, Kato N, Sasaki T. 2004. Association between the neurofibromatosis-1 (NF1) locus and autism in the Japanese population. Am J Med Genet B Neuropsychiatr Genet 131B: 43-47.

Mathis C, Collin L, Borrelli E. 2003. Oligodendrocyte ablation impairs cerebellum development. Development 130: 47094718.

Nissan MH, Pratilas CA, Jones AM, Ramirez R, Won H, Liu C, Tiwari S, Kong L, Hanrahan AJ, Yao Z, et al. 2014. Loss of NF1 in cutaneous melanoma is associated with RAS activation and MEK dependence. Cancer Res 74: 2340-2350.

Novak A, Guo C, Yang W, Nagy A, Lobe CG. 2000. Z/EG, a double reporter mouse line that expresses enhanced green 


\section{Sanchez-Ortiz et al.}

fluorescent protein upon Cre-mediated excision. Genesis 28: 147-155.

Reith RM, McKenna J, Wu H, Hashmi SS, Cho SH, Dash PK, Gambello MJ. 2013. Loss of Tsc2 in Purkinje cells is associated with autistic-like behavior in a mouse model of tuberous sclerosis complex. Neurobiol Dis 51: 93-103.

Roussel MF, Hatten ME. 2011. Cerebellum development and medulloblastoma. Curr Top Dev Biol 94: 235-282.

Samuels IS, Saitta SC, Landreth GE. 2009. MAP'ing CNS development and cognition: an ERKsome process. Neuron 61: 160-167.

Schubbert S, Shannon K, Bollag G. 2007. Hyperactive Ras in developmental disorders and cancer. Nat Rev Cancer 7: 295308.

Shukla V, Coumoul X, Wang R-H, Kim H-S, Deng C-X. 2007. RNA interference and inhibition of MEK-ERK signaling prevent abnormal skeletal phenotypes in a mouse model of craniosynostosis. Nat Genet 39: 1145-1150.

Skefos J, Cummings C, Enzer K, Holiday J, Weed K, Levy E, Yuce T, Kemper T, Bauman M. 2014. Regional alterations in purkinje cell density in patients with autism. PLOS ONE 9: e81255.

Staser K, Park SI, Rhodes SD, Zeng Y, He YZ, Shew MA, Gehlhausen JR, Cerabona D, Menon K, Chen S, et al. 2013. Normal hematopoiesis and neurofibromin-deficient myeloproliferative disease require Erk. J Clin Invest 123: 329-334.

Steinlin M. 2008. Cerebellar disorders in childhood: cognitive problems. Cerebellum 7: 607-610.

Tidyman WE, Rauen KA. 2009. The RASopathies: developmental syndromes of Ras/MAPK pathway dysregulation. Curr Opin Genet Dev 19: 230-236.

Timmann D, Drepper J, Frings M, Maschke M, Richter S, Gerwig M, Kolb FP. 2010. The human cerebellum contributes to motor, emotional and cognitive associative learning. A review. Cortex 46: 845-857.

Tsai PT, Hull C, Chu Y, Greene-Colozzi E, Sadowski AR, Leech JM, Steinberg J, Crawley JN, Regehr WG, Sahin M. 2012. Autistic-like behaviour and cerebellar dysfunction in Purkinje cell Tsc1 mutant mice. Nature 488: 647-651.

Wang VY, Rose MF, Zoghbi HY. 2005. Math1 expression redefines the rhombic lip derivatives and reveals novel lineages within the brainstem and cerebellum. Neuron 48: 31-43.

Wang Y, Kim E, Wang X, Novitch BG, Yoshikawa K, Chang LS, Zhu Y. 2012. ERK inhibition rescues defects in fate specification of NF1-deficient neural progenitors and brain abnormalities. Cell 150: 816-830.

Wechsler-Reya RJ, Scott MP. 1999. Control of neuronal precursor proliferation in the cerebellum by Sonic Hedgehog. Neuron 22: 103-114.

Xu H, Yang Y, Tang X, Zhao M, Liang F, Xu P, Hou B, Xing Y, Bao $\mathrm{X}$, Fan X. 2013. Bergmann glia function in granule cell migration during cerebellum development. Mol Neurobiol 47: 833-844.

Zhu Y, Romero MI, Ghosh P, Ye Z, Charnay P, Rushing EJ, Marth JD, Parada LF. 2001. Ablation of NF1 function in neurons induces abnormal development of cerebral cortex and reactive gliosis in the brain. Genes Dev 15: 859-876.

Zhuo L, Theis M, Alvarez-Maya I, Brenner M, Willecke K, Messing A. 2001. hGFAP-cre transgenic mice for manipulation of glial and neuronal function in vivo. Genesis 31: 85-94. 


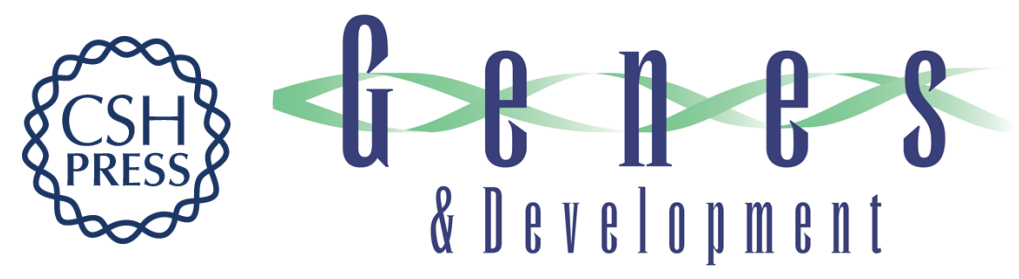

\section{NF1 regulation of RAS/ERK signaling is required for appropriate granule neuron progenitor expansion and migration in cerebellar development}

Efrain Sanchez-Ortiz, Woosung Cho, Inga Nazarenko, et al.

Genes Dev. 2014, 28:

Access the most recent version at doi:10.1101/gad.246603.114

\section{Supplemental} Material

References

Creative

Commons

License

Email Alerting

Service
http://genesdev.cshlp.org/content/suppl/2014/10/27/28.21.2407.DC1

This article cites 51 articles, 11 of which can be accessed free at: http://genesdev.cshlp.org/content/28/21/2407.full.html\#ref-list-1

This article is distributed exclusively by Cold Spring Harbor Laboratory Press for the first six months after the full-issue publication date (see http://genesdev.cshlp.org/site/misc/terms.xhtml). After six months, it is available under a Creative Commons License (Attribution-NonCommercial 4.0 International), as described at http://creativecommons.org/licenses/by-nc/4.0/.

Receive free email alerts when new articles cite this article - sign up in the box at the top right corner of the article or click here.

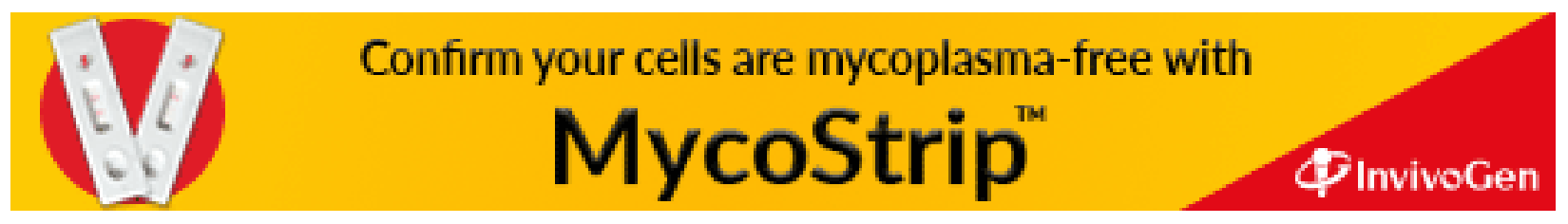

